\title{
Introduction
}

For me the war means Percy. ${ }^{1}$

When war broke out in August 1914, William 'Percy' Campbell volunteered immediately. Commissioned in the Wiltshire Regiment, he joined the 7th Division, fighting in the First Battle of Ypres. Killed in action on 24 October 1914, aged just twenty years, he had been on active service a mere seventeen days. His body was never recovered. Almost sixty years later, his younger brother Pat wrote a short fraternal memorial to his dead sibling. At the outset, he summarised the loss experienced by the war generation:

Everyone in Britain was in mourning. I myself lost many friends whom I loved and admired, but Percy stands for them all. For me the war means Percy. His was the courage and gaiety that was extinguished, his is the face I see whenever the war is mentioned.

In this simple statement, Pat entwined his memory of the Great War with the role his older sibling played in the conflict, affirming the relational infrastructure of this generation. To outsiders, Second Lieutenant Campbell epitomised the spirit of the patriotic volunteer, his life tragically cut short. Pat's sibling's-eye view presented his soldier-brother's character traits with balanced clarity, recording his own and his family's emotional responses to Percy's departure to the front, and the news of his death. Many others made similar efforts to record their siblings' war experiences, both of those who survived and of those who perished. Like them, Pat wanted his brother to be 'remembered for as long as I am'. This compulsion to 
give a voice to the individual war stories and personalities of dead brothers, to ensure they are not forgotten, forms a significant body of sibling memorialisation.

Typically, when fraternal relations are mentioned in the context of war, the image conjured up is one of intermasculine bonding, embedded in the ideal of esprit de corps. The privileging of comradeship through the overarching trope of the 'brotherhood of the trenches' has overshadowed the presence and significance of real sibling bonds. ${ }^{2}$ Brother-brother bonds have largely been ignored as a subject of historical and professional analysis. Often perceived as lesser than other sibling ties, brothers remain 'an absent presence'. ${ }^{3}$ Considerations of siblinghood in wartime have focused on sistersister or brother-sister bonds, exposing a different family dynamic. ${ }^{4}$ In particular, there has been little attention paid to liking or love in adult fraternal relationships. Looking at how brothers wrote to and about each other, and the myriad ways they 'brothered' or 'loved' one another, addresses this contracted viewpoint. Fraternal stories are embedded in First World War narratives, informing our understanding of the network of domestic ties sustaining men and of the performance of martial masculinities. Vital signifiers of fraternal affection are shown in the breadth and depth of the support, comfort and protection provided to both combatant and noncombatant siblings. If, as Michael Roper argues, men's domestic and military lives were 'structurally connected and interdependent', we lose a vital part of this network through the omission of sibling relations. ${ }^{5}$ Siblings shared an experience of war that differed from that of their parents. Presenting a cultural history of siblinghood in wartime, Brothers in the Great War addresses this significant gap in the historiography of the First World War.

\section{The war generation}

Siblings present an invaluable subject for research. These relationships are not only the longest standing over an individual's lifetime but also the most pervasive. During the eighteenth and nineteenth centuries the 'long family' (sizeable families with a wide dispersal of ages) was the dominant model. ${ }^{6}$ Falling fertility levels from the 
1870s onwards meant that by the Edwardian era this model was in decline. ${ }^{7}$ The average family size between 1900 and 1909 was 3.37 children, and continued to decrease steadily during the first decades of the twentieth century (to 2.90 in the period 1910-14 and 2.53 in the period 1915-19). ${ }^{8}$ One stated consequence of the emergence of the nuclear family is the gradual edging out of siblings from their traditional roles by quasi-kin - close friends and workmates. ${ }^{9}$ Notwithstanding the overall demographic trend towards the nuclear family, most children reaching adulthood in the 1910s experienced growing up with siblings within the far-reaching kin networks of earlier generations. ${ }^{10}$ Focusing on siblinghood at the beginning of the twentieth century, Brothers in the Great War demonstrates the continuing significance of these ties for the war generation.

Sibling groups considered in this study range from the intense sister-brother bond epitomised by Naomi and Jack Haldane, to examples of the 'long family' such as the seven brothers and three sisters of the Baines family. ${ }^{11}$ In 1914, Willie Baines, the eldest, was thirty-six years old; the youngest, Arthur, was seventeen. Six of the seven Baines brothers served in the war, three were killed in action, two were wounded and only one escaped physically unscathed. Two of the Baines sisters undertook pensions war work. Alongside their 'war' stories, their correspondence recorded their 'family' stories, including two marriages, one engagement and the death of Willie's daughter after a prolonged illness. While no family can be singled out as representative - class, religion and place all influencing familial dynamics - the Baineses' experience is certainly not atypical.

The prevailing 'vertical' focus on the mother-child relationship in particular has narrowed histories of the family and masculinities. This bias has drawn attention away from those family relationships such as siblinghood, 'less prone to change, less prone to state interference, and less prone to generate advice and prescriptive literature solely targeted at them'. ${ }^{12}$ A key finding emerging from the small body of sibling studies is the interaction between societal and familial norms. ${ }^{13}$ Shaped by external emotional codes, sibling interactions powerfully reflect the values and identity of individual families. Family life is not monolithic. Some sibling groupings, such as the four Hosegoods, Ralph, Gilbert, Arnold and Ellen, formed an 'inner circle' within the familial household. ${ }^{14}$ A lateral 
focus on familial relationships shows the agency of siblings in planning, resisting or initiating change. ${ }^{15}$ The cushioning effect of family culture at times of upheaval has obscured the role played by lateral ties, particularly the extent to which siblings influenced shifts in emotional norms both within and outside the domestic realm. ${ }^{16}$ Importantly, C. Dallett Hemphill highlights the crucial role of sibling cohorts as 'shock absorbers' during times of accelerated change. Generational solidarity enabled brothers and sisters to mediate transitions in social, political and economic life in mutually supportive ways. ${ }^{17}$ Consideration of the degree to which this mediating trait held in the context of twentieth-century siblinghood casts a fresh perspective on evolving emotional cultures in the post-war years.

Growing up together, brothers and sisters learn about, experience and change the world they have inherited. ${ }^{18}$ During the twentieth century this 'inherited' world included global conflict. Sibling ties, forged through shared childhoods, family practices, commitments and interests, were tested during long separations, trauma and bereavement. The concept of generations is inextricably linked with the First World War. Apart from the 'lost generation' of young men who sacrificed their lives, the myth of an alienated group of survivors is seared into our cultural memory. Building on Karl Mannheim's formulation of generations as agents of social change, June Edmunds and Brian Turner consider how the specificity of external traumas such as war generates 'an age cohort that comes to have social significance', uniquely cutting off a generation from its past and separating it from its future. ${ }^{19}$ Initially bonded by shared experiences, these groupings are further cemented by the institutionalisation of those experiences via rituals such as commemoration. ${ }^{20}$ Focusing on emotional interactions between brothers during the First World War and its aftermath, Brothers in the Great War explores how this cohort of siblings shaped the social and emotional lives of contemporary and future generations.

The 'myth' of a lost generation of elites is unsupported by the statistical evidence. In the post-war years, David Cannadine observes, the myth 'took on a life of its own', cementing its cultural significance. ${ }^{21}$ Generations are, by nature, a capacious category. The 'war generation' embraced men and women, combatants and 
non-combatants, men too old and too young to fight. These were not static categories; as the war progressed, men reached conscription age, or became eligible as the age parameters for combatants expanded. Each stratum presented its own experiences of war. Laura Ugolini has cast a welcome light on the experiences of middle-class 'civvies', one component of the 50 per cent of men of fighting age who did not fight. ${ }^{22}$ Others sought to explain their exclusion from dominant narratives of the war. One member of the Voluntary Aid Detachment (VAD) declared it was 'our war too'. ${ }^{23}$ A ten-year age gap distanced Stanley Bailey from his older brother, Frederick, killed in the war. Some fighting men experienced the war years as a period of stagnation, an 'everlasting no-ending sort of life', with no end in view. ${ }^{24}$ Soldier-brothers felt left behind, compared to siblings at home undergoing the more usual rites of passage into adult life. Jack Haldane had mixed feelings towards the domestic life of his younger sister, Naomi. Despite approving heartily of her relationship with his close friend, Dick Mitchison, for Jack their nuptials and the birth of their first child aroused conflicting thoughts. Writing in the third year of his service with the Royal Highland Regiment, he confessed his envy of his sibling's domesticity. ${ }^{25}$ Inevitably, he found this disruption to the 'natural order' disturbing. Soldiering had placed his life on hold.

'Demographic uncertainty' intensified during wartime. ${ }^{26}$ Siblings' roles shifted with the departure of men. Some men felt supplanted when younger siblings went out to the front before them. Thinking of his brother daily, Douglas Heaton found it 'simply maddening' not to have made it to the firing line, especially as the two brothers should have been serving together from the beginning. All he could do was wish his brother luck and promise to write as often as possible. ${ }^{27}$ Married men missed their children growing up, especially when comparing their circumstances with those of siblings remaining on the home front. Serving as a private with the Queens Own Yorkshire Dragoons, Friend Hammerton regularly wrote to his older brother, Richard. A colour blender in a worsted-spinning mill, Richard was exempted from service. ${ }^{28}$ Both siblings were married with young children. Their correspondence demonstrates how the brothers negotiated the apparent unfairness in their respective positions. Before his departure, Friend accepted the 'just decision to 
do my little bit for my country'. At the same time, he voiced the 'painful' tension between leaving his 'dear ones at home' and fulfilling his duty. ${ }^{29}$

A lateral view of generational experience and loss is inevitably bounded by networks of brothers, cousins, fellow students, friends and relatives. This was amplified by the naming of 'gangs' of peers such as the 'Three Musketeers' or 'The Coterie'. Such monikers embodied traits of exclusivity and loyalty. ${ }^{30}$ This relational micro-view, when coupled with a eulogistic tendency to extol the sacrifice of their peers, ensured that their loss was presented to the world on a macro-level. The sense of self-identification with the war generation was exacerbated by the sense that they alone, in the words of Vera Brittain, shared an 'instinctive and entire' understanding $^{31}$ - one that separated the contemporaries of this generation from their parents and children. Jack Foxell, writing to his brother after their sibling Edward's death, was thankful for their mutual sharing of loss:

At first it seemed as if I were very much alone ... But now I feel that it is our grief, not merely mine; and, though that does not lessen the grief, there is yet comfort in the thought. ${ }^{32}$ [Emphasis in original]

Familial communities of mourning extended beyond the boundaries of individual households, to those 'quasi-brothers and sisters' acquired vicariously via the friendships and romances made by siblings. Writing to his brother's sweetheart, Frank Cocker expressed the hope that she would always regard him as a 'brother willing and ready to help her at all times'. ${ }^{33}$ Despite this, siblings of both sexes experienced the loneliness of mourning, one shaped by the accumulated deaths of their peers - an emotional solitude that was undiminished by the passage of time. Rather, growing older in the absence of loved ones added poignancy to life events such as marriage and birth, when familial happiness mingled with grief, guilt and anger. Brittain regretted that those she held dearest at the time of writing Testament of Youth (1933), her husband and children, 'did not know even by name a single contemporary who counted for me in the life before 1918'. Initially experiencing a sense of forlorn bitterness, she eventually grew hardened 'to revisiting that past world, alone'. ${ }^{34}$ In her consideration of Ruth Holland's 
The Lost Generation (1932) and May Wedderburn Cannan's The Lonely Generation (1934), Sharon Ouditt observes how the grief of female protagonists became problematic for later generations focused on reconstruction and forgetting. ${ }^{35}$ This gendered perspective is repeated by Tammy Clewell, who sees Virginia Woolf's textual practice of mourning as a 'gendered rebellion against the act of closure', presenting her grief as an ongoing, anti-consolatory process. ${ }^{36}$ What renders such analyses problematic is their failure to widen the scope to consider how men's writings about grief and unresolved mourning fit into wider patterns of bereavement in the post-war years.

\section{Siblings in wartime}

Exploring sibling relations during wartime offers a prism through which to analyse both martial and familial emotions: how did fighting men maintain these bonds, and how did their experiences affect and shape these relationships? War provides an atypical backdrop against which to examine fraternal ties. Approximately two-thirds of fighting men in the Great War were single. This, combined with their relative youth, meant that sibling ties were an important source of emotional and practical support. ${ }^{37}$ Brothers and sisters represented continuity and stability in disruptive times. As the mounting casualties seeped into the everyday reality of millions of families, sibling grief was overlooked, often subsumed by that of their mothers. Efforts exerted by surviving siblings to preserve the particular war stories of soldier-brothers are testimony to the longevity and depth of their bonds.

Accounts by siblings provide a near-peer-level perspective on the effect of war on family members. Adopting a chronological and thematic approach, Brothers in the Great War examines siblings' experiences at key transitional moments, such as departing for war, experiencing technological combat or undertaking war work alongside each other. In contrast to their soldier-brothers, the accounts of non-combatant siblings are grounded in the experiences of the home front. Although the myth of the 'rush to colours' by eager volunteers has been challenged, studies perpetuate the 
gendered expectation that 'real' men fight wars. Susan Grayzel and Tammy Proctor suggest that this led to men embracing their duty, with many viewing the experience as a great adventure. ${ }^{38}$ While the familiar tropes of war fever and patriotic duty appear in the accounts considered in this study, the sibling's-eye view of brothers and sisters demonstrates the underlying trepidation that accompanied departures for war. Battle-hardened siblings were quick to caution brothers to 'keep out' of it if possible, or at least to avoid the worse arenas of battle. Retrospective accounts show siblings' remorse over their earlier war fever. Omissions are indicative of sibling guilt. In her memoir, Vera Brittain notably excised her initial war enthusiasm and active support for Edward's war service against stiff paternal opposition. She recorded this in her diary as a generational battle. Their father failed to understand the codes of honour instilled in his son - the first in the family to attend public school. Faced with paternal disregard for her brother's honour or courage, it was left to the siblings 'to live up to our name of "Brittain". 39

Evidence from experiential narratives, press reports and the military service tribunals demonstrates the complex weighting of sibling and family duty versus service to nation. Pressure was exerted on siblings to alleviate the war stress of families, especially mothers. Mancunian Tom Povey directed his sister Alice, a domestic servant, 'to come home $\&$ help ... for Ma cannot manage as it is'. He also advised his brother to 'stick to home $\&$ do his best for $\mathrm{Ma}$ ' as he would willingly do 'if I could get out of this' ${ }^{40}$ Reacting to the view that the family badly wanted 'someone' at home, following the deaths of John and Joseph Baines in July 1917, Dodo suggested that Tom, the second-eldest, should obtain a home appointment. As 'someone' acted here as a euphemism for one of the remaining soldier-brothers, the fraternal wisdom determined that it was Tom's 'place' to soothe familial anxieties by removing himself from the dangers of front-line action. In Dodo's view, the totality of war service of the seven siblings should merit such a move. ${ }^{41}$ This matter took on greater urgency following Dodo's death in June 1917.42 Believing that by 'offering all they can', smaller families stood to lose all, Tom discounted this argument. Somewhat optimistically, Tom believed it unlikely that all six brothers would be 'bowled out. ${ }^{43}$ 
Service kinship created a nexus for the organisation and recruitment of the British armed forces. ${ }^{44}$ The familial ideal was an integral part of army organisation, displacing attachments to home with an emotional bond to the regimental family. ${ }^{45}$ As Hugh Childers, the army reformer tasked with 'humanising' the Victorian army, spelt out in 1884, recruits should feel a sense of belonging to their regiment, that it was 'their family'. ${ }^{46}$ Significant numbers of brothers enlisted and served together in the Pals and the Territorial units, exhibiting the strength of real blood ties. Three of the Tattersall brothers, Albert, Norman and John (soon to be Privates 17232, 17233 and 17234), joined the Manchester Pals. ${ }^{47}$ Partially inspired by Edwardian civic pride, the Pals movement took root in the industrial towns of the north of England. ${ }^{48}$ Men wanted to serve with their friends, neighbours and workmates, rather than with strangers. ${ }^{49}$ Five sets of brothers are among the 221 names recorded in the Preston Herald's Roll of Honour of Preston Pals departing for training on 8 September $1914 .{ }^{50}$ Alongside the local and occupational spheres of masculine association forming the core of the Pals battalions, we must add familial and fraternal identities. Despite frequent references in men's personal narratives, this component of Kitchener's army is largely absent from the historiography. The predominant focus on comradeship mutes fraternal war stories. What makes this more surprising is the long-established army principle that an older serving brother could 'claim' a younger sibling to serve alongside him. ${ }^{51}$ This could be deployed as a protective measure. When Thomas C. volunteered in 1915, he was surprised when informed by the War Office that he was to serve in the 2nd West Lancashires. Reacting to their mother's concerns that Thomas would join an 'infantry mob', his brother had exercised his fraternal privilege to claim his under-sized brother as a trumpeter. ${ }^{52}$

Accounts suggest that brothers derived strength from serving 'side by side' or in close proximity. These fraternal affiliations surpassed the fictive brotherhood of the trenches by bolstering resilience. Reservist Robert Hill was swiftly dispatched to France, joining the 1st Battalion Kings Liverpool, where he unexpectedly found his 'own big brother'. ${ }^{53}$ Sharing confidences, news and parcels from home gave soldier-brothers a much-welcomed respite. Close contact with brothers eased pre- or post-battle anxieties. In 
turn, men could reassure family members at home of their sibling's wellbeing. Such domestic comfort came at a price. Combatants witnessed the woundings and deaths of brothers and waited anxiously for news when siblings failed to return after an offensive. The solidarity shared by combatant brothers is compared to sisters undertaking war work together and those families where one or more brothers fought, and one or more chose to exercise their conscientious objection to war under the Military Service Act $1916 .{ }^{54}$ Engrained family values meant that affectionate relations were maintained, regardless of opposing stances to the war. Private Phil Brocklesby, writing home to his mother on the eve of the Somme battle, said he was 'right proud' of his brother Bert, recently imprisoned for his absolutist stand. When Bert was arrested, their lay preacher father had declared he would rather see his son shot than abandon his beliefs. ${ }^{55}$ Although Phil volunteered, familial unity ensured that the fraternal bond remained intact. Given the public disparaging of 'shirkers' and 'slackers' during wartime, this proffers significant insight into the emotional effort invested in sibling ties. ${ }^{56}$

\section{Brotherhood}

The monument designed to commemorate the ill-fated British Antarctic Expedition, 'Pro Patria', depicts a figurative allegory of Courage sustained by Patriotism, spurning Fear, Despair and Death. ${ }^{57}$ Designed by Albert Hodge, it illustrates the elements of manly heroism and sacrifice that captured the public's imagination, prompting scenes of mass mourning for the failed venture. ${ }^{58}$ Inscribed below Hodge's figures are the words 'For King', 'For Country', 'For Knowledge' and, notably, 'For Brotherly Love'. On the eve of the First World War, brotherly love in the form of stoic comradeship received a very public endorsement. ${ }^{59}$

Fraternal relationships have long figured as an idealised 'brotherhood' - traditionally emphasising loyalty, mutual dependence and equality. ${ }^{60}$ The language of brotherhood and, less frequently, sisterhood designated the strength and intimacy of particularly close friendships. Organisations such as the Freemasons, trade unions, friendly societies and the Co-operative movement 
drew upon kinship terminology to explain and define their underpinning ideology. ${ }^{61}$ Framing standards in this way enabled hierarchical organisations to be seen as 'quintessentially egalitarian', further embedding fraternal relations in the cultural imagination. ${ }^{62}$ Similar efforts institutionalised and structured these private and personal bonds within the Edwardian education system. ${ }^{63}$ In his 1908 poem Clifton Chapel, the 'poet-spokesman for the public schools', Henry Newbolt, referenced the imperialist brotherhood 'that binds the brave of the earth' ${ }^{64}$ Drawing a similar comparison, Henry Montagu Butler, headmaster of Harrow, stated it was 'public school brotherhood' that sustained their alumni fighting in the South African war during days 'of trial, of danger and of suffering'. ${ }^{65}$

Esprit de corps, or male bonding, became one of the enduring tropes of the Great War, with the figure of the bereaved male friend becoming its representative par excellence. ${ }^{66}$ Recognition of the pivotal nature of this allegiance among fighting men informed military training. ${ }^{67}$ During wartime, the phrase 'brothers in arms' denoted a sharing of traumatic experiences. Countering the regular soldier's apparent rejection of organised religion on the front line, Anglican chaplains held up the military's 'strong sense of brotherhood' as proof of the inherent Christianity of the Tommy. ${ }^{68}$ Anxious to repudiate the poor image of soldiers and army life, the Church of England highlighted the moral spirituality of soldiering as the 'beautiful brotherhood of the trenches' ${ }^{69}$ Such brotherhood extended to the enemy, with semi-ironic references to 'Brother Bosch' or 'Brother Fritz'. ${ }^{70}$ The British Legion later drew on this soldierly brotherhood in its rhetoric and insignia. ${ }^{71}$ Many conscientious objectors used the concepts of universal brotherhood or fellowship to justify their pacifist or socialist stand against the war. ${ }^{72}$ Propagandists grasped the appeal of inserting siblinghood within the discourse of patriotic war work. Hall Caine coined the term 'Tommy's Sister' for the 'army' of women workers at the Woolwich Arsenal. ${ }^{73}$ Women's service organisations, wishing to match the loyalty of soldierly fraternity, established a legend of sisterhood. ${ }^{74}$

Pitched against idealised standards of brotherhood are examples of real sibling bonds emerging from men's experiential accounts. These present a more complex picture. The parameters of what constitutes brotherly love and duty in the domestic sphere are hard 
for men to pin down, complicated as they are by the uniqueness of sibling relations, with their inherent characteristics of sameness and difference. ${ }^{75}$ Familial circumstances, allegiances and responsibilities alter over time. When sibling bonds are strong, they provide a 'sustaining link' to brothers and sisters throughout their life course. ${ }^{76}$ Santanu Das makes the important point that while the individual bonds of 'comradeship', 'friendship' and trench 'brotherhood' each had its own particular nuance and value, they all fed into the continuum of male relationships under extreme conditions. ${ }^{77}$ What emerges is an informal 'taxonomy of friendship', including 'marital friendship and friendship within families, friendship between equals, and friendship across boundaries of age, of sex and of social class. ${ }^{78}$ This is seen in the labels applied to men and women in particular circumstances. Cultural expectations informed depictions of men as sons, brothers or comrades and women as mothers, sisters, workers and widows, reinforcing stereotypes circulating in wartime discourses of patriotism, sacrifice, service and grief. Men's articulation of male bonds shows the continuum of brotherhood and friendship. Billie T. was not only a brother to his younger sibling but also a 'good friend', taking his part in everything. ${ }^{79}$ Combatants' narratives include many portrayals of intense friendship bonds. After three 'good mates' were killed on 22 September 1917, Harry Patch outlined his terrible loss:

It was like losing part of my life. I'd taken an absolute liking to the men in the team - you could say almost love. I mean, those boys were with you night and day: you shared everything with them and you talked about everything. You were one of them, we belonged to each other. ${ }^{80}$

In his expanded definition of comradeship, Patch referenced traits mentioned by brothers: his sense of intimate knowledge and belonging forged by the soldierly practices of the front line, rather than the sibling practices of the family home. The particularity of this Great War friendship was underscored by the fact that, like many veterans, Patch was uninterested in meeting former comrades after the war. ${ }^{81}$ Sisters experienced a different continuum, from brotherly friendship to romantic entanglement. Bevil Quiller-Couch was 
amused to overhear his future fiancée, May Cannon, refer to him as 'a kind of brother'. Sixteen-year-old Naomi Haldane's youth and inexperience contributed to her difficulty in adjusting to a more physically intimate bond with her fiancé. Apart from unwanted 'words and touches', it had been 'something of a shock' to find that her relationship with someone she had considered 'as a brother ... had suddenly turned into something else'. This adjustment might have been easier had it been possible to take things at a slower tempo, but, Haldane explained, 'there was a war on and nothing could wait' ${ }^{82}$

\section{Sibling practices}

Sibling roles and dynamics lack definition, dependent as they are on a range of factors including age, family size, birth order, personality and shared interests. Within the same family, ties between brothers and sisters varied. One woman interviewed as part of Paul Thompson's FLWE study summarised the difficulty of pinning down these relationships, explaining how they played out in the specificity of her own sibling group:

Well - in a family - there's what you might term brotherly love, and that can cover an awful lot. You see. Both ways, love, hate, love, hate, love, hate. Now, my brother Jack, I don't think - ever - said a cross word to me in the whole of his life ... Whatever I did he would make an excuse for it ... But my sister, well he'd box her ears. You see, you never know in a family. ${ }^{83}$

Although birth order was often the key factor determining responsibilities, both older and younger children understood the subtlety of intra-familial power relationships, wielding an element of policing to ensure that expectations and resources were met and shared. Some sibling groups drifted into 'little power units'. ${ }^{84}$ Older siblings acted as an intermediate generation between parents and younger children in long families. ${ }^{85}$ Parental influence held greater sway for older children, overlapping with their parents in adulthood. ${ }^{86}$ Complexity was added within 'blended' families. In the later decades of the nineteenth century, marriages were most likely to be 
terminated by death. Thirteen per cent of unions in the 1880 s were ended by a death within ten years, rising to 47 per cent after twentyfive years. ${ }^{87}$ Remarriages created their own groupings or 'mixed litters' ${ }^{88}$ Robert Graves was the third child of Alfred Graves' second marriage to Amelie 'Amy' von Ranke in 1891. Alfred's first wife, Jane Cooper, had borne him five children.

Brothers were expected to fulfil many roles within the immediate family: as head of household after a father's death; as breadwinners; as protectors and as carers for younger siblings. Born in 1900, James B. worked as a bandolier inspector in the East End before joining the army in 1918. Practically and emotionally, James assisted his siblings, stating, 'I used to love 'em. I couldn't do enough for 'em. If I could help 'em - oh yes, I always helped me brothers and sisters. ${ }^{89}$ In his absence, one sister, the 'mother' of the family in childhood, stepped back into this matriarchal role. Sometimes the adopting of roles led to resentment. When Thomas B.'s brother, the elder by two years, 'took charge' after their father's death in 1913, his assumption of responsibility rankled, especially his tendency to 'order' his younger sibling about. ${ }^{90}$ John E., the self-proclaimed 'kingpin' of his sibling group, explained that even though the seven younger ones sometimes rebelled, a combination of obedience to one's elders and the knowledge that they could rely on him kept them in line. ${ }^{91}$

Observational studies of children have shown the influence of older siblings when they act as teachers or role models. ${ }^{92}$ When family configurations or circumstances make older brothers more 'visible' than fathers, sociologist Rae Connell argues, they exert greater influence in developing masculinity. ${ }^{93}$ The eldest of six brothers and one sister, Arthur S. afforded essential practical and financial support to his siblings. They 'seemed to look up to me' he explained, 'cause I was the eldest'. ${ }^{94}$ Stanley R. got 'good' direction from his brothers, both for guidance and as manly templates. ${ }^{95}$ Ability cemented roles. Smartness and capability made the eldest sister of one man the best source of advice. ${ }^{96}$ By expanding our conception of 'brothering' and 'sistering', Brothers in the Great War provides a missing link to changes in twentieth-century parenting practices that an over-reliance on expert and popular discourses cannot fully explain. ${ }^{97}$ 
Shifts in familial duties and roles occasioned by wartime service became permanent upon the severe wounding or deaths of brothers, disrupting familial responsibilities and obligations. ${ }^{98}$ Filial devotion inspired these attempts to lift the burden from grieving parents. After his older brother's death, Ralph Hosegood 'surprised' his father by offering to take his brother's place in the family corn merchants business. Ralph, a qualified solicitor, was an active participant in Bristol's legal community. His offer represented a significant shift in his post-war expectations. Ralph also shouldered the difficult task of going to his youngest brother's school to inform him of their loss. ${ }^{99}$

Representing the double loss of both a stable family figure and a close companion, the emotional and practical impact of a sibling's death on their surviving brothers and sisters has been largely overlooked. ${ }^{100}$ Improved mortality rates in the late nineteenth century increased the longevity of sibling bonds. Individuals born in 1900 could expect that 60 per cent of their siblings would still be alive when they reached the age of fifty. ${ }^{101}$ Commentators have noted the effect of wartime deaths on parents who, due to falling mortality rates, expected their children to outlive them. However, there has been little scrutiny of how these losses affected siblings who would have expected to grow old alongside their brothers.

Siblings, familiar with their placing in the family order, suddenly assumed different roles. For titled families, the laws of primogeniture made the death of a childless male heir particularly significant. An analysis of the timing of life-cycle events such as births, marriages and deaths in the late-nineteenth and early twentieth centuries bears this out. A child born as late as 1891 would be aged about thirtyseven when their father died. ${ }^{102}$ Based on the age at which children might expect to receive any inheritance, this was also when elder siblings of both sexes might shoulder some or all parental or 'head of family' roles. Wartime casualties forced these upon them at a much earlier age. Tamara Hareven considers the centrality of timing in the scheduling of family events and the transition of individuals into different family roles. Life-cycle stages such as leaving school, marriage and the birth of children resulted in divergences and convergences within sibling groups as the focal attention of their lives shifted accordingly. Rich in detail about life on the home front, a 
central focus of the wartime diaries of Ella Lethem and Gwyn Wells are their sweethearts and marriage preparations. ${ }^{103}$

Accompanying these stages was a widening of friendships within their peer relationships and kin networks as siblings gained in-laws and nephews and nieces. Shortly after the birth of Maurice Foxell's first child, the unexpected arrival of a 'booted and spurred' Edward Foxell, ten days before his departure to the front, meant he was the first uncle to see the 'sweet baby'. ${ }^{104}$ Sometimes boundaries between friendships and kinship bonds became blurred or unsettled post marriage or engagement. Waiting to find out if her fiancé had obtained leave, Ella Lethem was disconcerted when a letter from him arrived for her brother Tom, as it 'seemed quite funny' for anyone else to get a letter from Douglas. ${ }^{105}$ The previous year, Douglas, a good friend of Ella's older brothers, had stood in for Tom as best man at John Lethem's marriage to Gladys Caxton. Tom, then serving as a private, had been delayed returning on leave, causing him to miss the service. ${ }^{106}$ After Peggy Hamilton's brother Oliver married her close friend Ursula Carr, she spent her leave at their marital cottage at Orford, not far from Oliver's base. 'It was so lovely' being with them, she wrote in a letter home, 'that I didn't leave the next day, or indeed the one after that.'107

When siblings left home for education, for work or to establish households, they maintained relationships and interactions by visits and correspondence - patterns of behaviour that continued during wartime. Evidence from social surveys of urban life conducted by Charles Booth and Seebohm Rowntree in the 1900s shows that after leaving the family home, siblings often lived in the same or neighbouring streets. ${ }^{108}$ Fraternal networks remained strong throughout the first half of the twentieth century. Young and Willmott's study of family and kinship in Bethnal Green found that over a quarter of the 755 brothers surveyed had visited a brother in the previous week, a finding replicated by Rosser and Harris's (1965) analysis of families in Swansea. ${ }^{109}$ Affectionate bonds persisted into old age, with some sibling groups in daily or weekly touch. This explains why accounts of front-line brotherly visits feature so heavily in wartime narratives. These could be chance encounters, but some men went to great lengths to track down and spend time with their soldier-brothers. 
Serving with the Royal Army Medical Corps (RAMC), Gilbert Baines traced down his brother Arnold with difficulty after hearing his brother's regiment was in Ypres. Arnold's transfer to another regiment complicated his task, delaying his arrival in the vicinity. Gilbert's joy at their eventual meeting was expressed by his emphatic declaration, 'At last. I have seen Arnold.' 110 When leave was scarce, meeting up provided an immediate connection to men's domestic lives. ${ }^{111}$ Although sisters serving on or near the firing line in the VAD, First Aid Nursing Yeomanry (FANY) or Women's Army Auxiliary Corps (WAAC) potentially had the opportunity to meet up with their brothers, accounts of such meetings are rare. More often, it was periods of leave that allowed brothers and sisters to catch up with each other. This reflects the bias in the source material which privileges the experience of women on the home front. Siblings of both sexes eagerly anticipated meeting up, repeating patterns of leisure established before the war: eating out; visiting friends and family; going to the theatre or cinema or enjoying long walks. When Alf Wells arrived home for his eagerly anticipated leave in April 1918, he enjoyed a full day of activities with his sister Gwen. After lunching at the Strand Corner House, they saw the musical comedy The Boy. Hearing of their plans, their younger sister, Peggy, accused Gwen of selfishness. Gwen, a civil servant, had the forthcoming Monday off to spend more time with their brother. ${ }^{112}$ Their sororal spat revealed the emotional import of leave for siblings at home.

\section{Sibling love}

Deep affection for brothers is commonplace in siblings' narratives. We see it in their descriptions of their bonds, in their practical, emotional and economic acts of caring, in their anxiety over loved ones and in their anger, grief and guilt over their deaths in combat. Brothers in the Great War complements the growing scholarship on fatherhood and romantic love in the twentieth century by drawing attention to this neglected aspect of men's emotional development. ${ }^{113}$ Clinical focus on sibling rivalry has obscured the dimension of sibling love. Valued relationships in 
their own right, sibling bonds are diminished when brothers and sisters are reduced to being competitors for parental love. ${ }^{114} \mathrm{We}$ must not equate the absence of an explicit verbal language of love to represent affectionate sibling ties with an absence of profound feelings. ${ }^{115}$ To fall short of describing them as loving relationships is to diminish their emotional significance. Adopting the term love in its fullest sense as defining bonds that are characterised by deep affection or fondness, or a strong emotional attachment based on mutual affinity and manifesting itself via concern for the other's welfare or pleasure in their company, it becomes clear that many brothers and sisters were articulating loving relationships with their siblings. ${ }^{116}$

More scholarly attention has been paid to the sister-brother bond in wartime. Our knowledge of these relationships is largely shaped by an influential group of middle-class women writers. ${ }^{117}$ In Angela Woollacott's memorable phrase, serving men 'loomed as the dominant planets' in their sister's lives. ${ }^{118}$ Scholars have argued that brother-sister and sister-sister bonds assumed an emotional salience during the Victorian period. ${ }^{119}$ Middle-class sisters grew up in a hot-house of expectation and ambition, with boys 'destined to achieve' - a sororal perspective that doubtless fed into the myth of a lost generation. ${ }^{120}$ Accounts show how fraternal relationships expanded the social and educational horizons of young women's highly chaperoned lives. Overcoming a five-year age difference, Jack and Naomi Haldane shared many interests, from reading poetry to playing literary word games, walking and going to 'flea-pittish' cinemas and the theatre. For Naomi, who, like Vera Brittain, found her daily life constrained by conventional attitudes to young women, these were welcome injections of liberty. No wonder she described it as a 'deeply exciting' relationship. ${ }^{121}$ Indicative of their intellectual focus on the separation of public and private spheres in middle-class households, Leonore Davidoff and Catherine Hall believed that, of all familial relationships in this period, sisters were the closest. Sisterly bonds, cemented in the domestic realm, were largely undisrupted by the periods of educational and occupational absence that were almost inevitable for their brothers. This inference privileges physical proximity as a contributory factor in establishing affectionate middle-class sibling relations. 
There has been less of a focus on working-class sister-brother and sister-sister bonds. Evidence from Paul Thompson and Trevor Lummis' qualitative survey of Edwardian family and working life (FLWE) points to similar patterns of sibling behaviours forging close emotional ties. ${ }^{122}$ Henry T. was a 'particular pal' of his secondeldest sister until his death in the war. ${ }^{123}$ Some ties did not depend on physical presence. Elizabeth E. remained close friends with her sister all their lives, weathering the absences occasioned by her sibling's domestic service. ${ }^{124}$ The two eldest sisters of one Staffordshire family were especially close, 'doing everything together'. They carved out time from their hectic household of seven, sending the younger ones off to bed and sharing a cup of cocoa. ${ }^{125}$ One mill worker recalled her eldest brother taking her out a lot before his marriage. Sharing an interest in music, they attended concerts at Albert Hall in Bolton and productions by local amateur operatic societies. ${ }^{126}$ Extreme poverty and employment opportunities were cited as the cause of breaches in working-class sibling ties. The continuing bond between one pair of sisters as domestic servants was reliant on their respective employers agreeing that they could take the same day off, a level of mistrust making this a rare occurrence. One later reflected on the 'terrible sacrifice' imposed by their employment, which resulted in the sisters losing touch. ${ }^{127}$ Workingclass sisters also formed friendships through fraternal connections at school and the workplace. Working long hours in the family laundry business, Gladys C. had limited opportunities to forge friendships with either sex. During the war, she regularly wrote to two male friends whom she had met when her brother brought them home. ${ }^{128}$

FLWE respondents rarely used the words love or loving in relation to familial relationships, including those between parent and child. ${ }^{129}$ The inherent complexity of siblinghood made it hard for siblings to define their bonds, to understand what behaviours and emotions signified 'real' brother- or sisterhood. Close relationships, as defined by psychologist Harold Kelley, are characterised by 'strong, frequent, and diverse interdependence' between two people, lasting a considerable period. ${ }^{130}$ Markers of harmonious sibling relationships were framed in terms of happiness, unity or friendship, one man describing his fraternal bond as 'a long 
friendship that we retained all our life, ${ }^{131}$ an inherited orientation of family values and siblinghood that provided lifelong sustenance. References to unity are particularly pertinent. Family happiness, suggests Sara Ahmed, involves 'a way of being aligned with others, of facing the right way'. The family becomes happy through the work that must be done to keep it together. ${ }^{132}$ Clannish families, rallying practical, financial and emotional support, were more likely to thrive. Consequently, parents encouraged children to respect one another, to be tolerant or kind, and exhorted them not to quarrel or fight. Instilled from an early age, this deep sense of bonding not only explains men's urge to enlist and serve alongside each other but also why siblings' domestic responsibilities remained intertwined even after they left home.

Brothers were reluctant to publicise broken relationships, being mindful of familial sensitivities; adherence to the cultural taboo against 'speaking ill of the dead' combined with a desire to eulogise siblings. Emma Griffin makes the cogent argument that 'darker aspects' of working-class intimate life must not be obscured by a focus on affectionate bonds, especially where emotional experiences of parental neglect or abuse may be absent from autobiographical accounts. ${ }^{133}$ 'Bad' siblinghood is harder to categorise. Brothers and sisters may experience a negative relationship with only one member of their sibling group. Examples of 'bad' brothers must be distinguished from the perhaps inevitably distant relationships resulting from age gaps or intra-family groupings. For example, Mr Keble was in his mid-twenties when the youngest of his ten siblings was born. There was no discord between the children. The older ones were simply 'out of touch' with their younger brothers and sisters because of the familial age span. Explicitly unfavourable accounts were often justified or explained by a breach in societal or family values: a failure to perform fraternal or masculine obligations. The end result is an unavoidable bias towards loving or affectionate fraternal relationships in the source material examined within Brothers in the Great War.

War itself disrupted fraternal ties. These 'distances' and 'disruptions' do not necessarily equate to negative relationships but, rather, correlated with a lack of emotional closeness during 
distinct, often transitory periods of the fraternal life course. Where men led separate lives or experienced a rupture in relations, this was likely coupled by a corresponding breakdown in correspondence or contact. When Clifford Allen fell out with his brother Godfrey over their divergent views on the war, he was unable to get over the loss of 'the last vestige of ordinary home life'. Later he expanded on the pain resulting from their estrangement. Able to bear a separation borne of marriage, it was 'very hard' to lose his brother's friendship and feel 'more of a stranger with him than with many a political acquaintance'. ${ }^{134}$ The rift between the Allen brothers was short lived. Godfrey later joined Clifford in southern France, where he was convalescing, his ill health being a consequence of his imprisonment. Snapshots of ill-feeling can be misleading; siblings united in times of need, or reconciled their differences with the passing of time.

\section{Domestic ties}

Historians have examined the strong pull of familial ties, and combatants' use of domestic metaphors to sustain ties to the landscapes of home. ${ }^{135}$ Such bonds played a vital role in building up resilience, helping men to endure and survive the traumas of war. Reliance on the indisputable fact that mothers were the main recipients of letters sent home by soldiers on the front has had a reductive effect on interpretations of the range of support offered by brothers and sisters. ${ }^{136}$ By focusing on this strand of familial support, Brothers in the Great War adds to the growing body of evidence demonstrating the primacy of domestic ties for fighting men. ${ }^{137}$ Collections of sustained fraternal correspondence testify to the distinctiveness of these relationships within the family unit. Young men transcended the liminal experiences of war by turning to a wistful substitute for their former lives, easily accessible through exchanges about the home, school and leisure activities of younger siblings. Fraternal support included the routine activities of sending letters, reading materials and practical masculine items. Brothers and sisters also received confidences, harrowing tales of life on the front line and expressions of anxiety, loneliness and grief. 
Certain details were explicitly to be withheld from parents. In this important way, brothers and sisters supplemented the maternal support given to combatants, while sharing the filial burden of shielding mothers from the full horrors of war. Hospitalised with bronchitis, a vexed Dodo Baines wrote to his brother. Despite his giving Ralph's name as next of kin, the War Office had wired their mother, frustrating their 'arrangement'. Four months later, when Dodo was seriously wounded, Arthur Baines determined to spare their mother, initially reassuring her that Dodo was 'well on the way to recovery'. Over the following five days, Arthur punctiliously monitored his brother. When Dodo's condition deteriorated after an operation to amputate his leg, Arthur finally informed his family. Later that same day, Dodo died. ${ }^{138}$ These acts of filial collusion served a double purpose. By protecting their mothers, siblings managed familial levels of anxiety at a distance, while simultaneously reducing the strain of managing their own and familial unease over the wellbeing of loved ones.

Siblings strove to maintain pre-existing familial caring and economic relationships during periods of enforced separation sustaining brothering and sistering at a distance. ${ }^{139}$ Prominent among the factors forging sibling bonds - power, affection, duty, obligation and reciprocity - are acts of caring. ${ }^{140}$ Separating the acts comprising caring from the emotions underlying them narrows our understanding of these interactions. ${ }^{141}$ David Morgan's concept of family practices shows how people 'do' relationships in their regular, everyday activities. ${ }^{142}$ The overall familiarity of domestic life, and intimate knowledge of familial idiosyncrasies, defined these emotional relationships. ${ }^{143}$ Sibling relations foster a sense of identity through everyday interaction and emulation, reinforced by engagement in 'sibling practices' - regular chores, mealtimes, bedtimes, playing, walking to school and sharing clothes. ${ }^{144}$

Such routines have a spatial and bodily aspect: the cramped conditions of communal sleeping; familiarity with naked or semiclad bodies; wearing hand-me-downs; and the restatement of sibling hierarchies by the allocation of set places at mealtimes. The associated physicality of such everyday ritual cut through the 'cerebral and bloodless' nature of late-Victorian and Edwardian manliness. Enmeshed in all aspects of daily life, siblings gained a 
'fundamental' understanding of each other. ${ }^{145}$ Growing up together bred a familiarity that rendered sibling relationships unremarkable, men and women often switching from the individual to the plural 'we' or 'us' in their accounts of childhood. A key benefit of Morgan's approach is that it encompasses all family interactions. Shifting patterns of family relationships can be examined outside of familiar settings and activities. ${ }^{146}$ The sense of belonging, grounded in early childhood experiences, remained with siblings into adulthood, infiltrating all areas of their lives. ${ }^{147}$ Interactions forged in childhood practices were translated into sibling support during wartime.

Mass recruitment, as John Bourne observed, created a British army that was overwhelmingly working class and urban, creating a bedrock of social cohesion and community that was heavily influenced by working-class family values. ${ }^{148}$ Brothers in the Great War's call for a reassessment of wartime masculinities is founded on important evidence that gendered expectations of caring were not as polarised as previously depicted. A common assumption is that these responsibilities were carefully choreographed, with individual family members having clearly assigned roles. While recognising the existence of a gender bias in the assignment of caring duties, men's accounts affirm that 'mucking in' - the participation of all siblings in household chores, dependent on what was required - was a more accurate reflection of the household routines of many sprawling working-class families. Julie-Marie Strange draws on Daniel Miller's work to recast men's routine acts of providing for families as ones of love or devotion, circumventing the gender-based labelling of caring and breadwinning roles. ${ }^{149} \mathrm{~A}$ focus on similar mundane interactions between brothers will reveal the emotional underpinning of each fraternal bond growing out of these workaday tasks. Family bonds may be more tender or intense because economic relations are critical to mutual survival. ${ }^{150}$

Roper acknowledges that the roots of the 'rough, protective care' provided to each other by serving men lay in pre-war friendships and relationships with brothers and sisters. He challenges its categorisation by some historians as 'paternal', preferring instead to call this behaviour 'mothering'. ${ }^{151}$ Such gendered labelling of these roles diminishes the distinctiveness of siblinghood: acts of brothering 
differ from those of mothering and fathering. Men invested fraternal acts of caring and protecting with affective significance, akin to that observed by the children of breadwinners. ${ }^{152}$ Routine caring by and for working-class brothers offers up a positive counterpoint to the dominant stereotype of young working-class men as one of 'youth in trouble' or 'youth as trouble'. ${ }^{153}$ Depending on the make-up of individual families, brothers watched over their younger siblings. Such responsibilities should not be dismissed as 'light' duties; childhoods could be blighted by familial duties. ${ }^{154}$ As the second-eldest of five, Frank B. resented having to take care of his younger siblings, explaining, 'I used to be put on.' ${ }^{155}$ For some, bearing the 'brunt edge' of caring for younger siblings marred their sibling relations; for others, caring or being cared for formed the essential bedrock of their bond.

Annette Atkins' definition of 'family culture', the rules, values, expectations and standards by which families measure themselves and each other, is 'powerful enough to offset the values, rules, and expectations in the larger culture, especially about gender'. ${ }^{156}$ This latter point is a material consideration when looking at siblings' nurturing roles. Paternal and caring roles performed by brothers played a significant role in forging and deepening brotherly affection. Gratitude aroused by fraternal protectiveness recognised that such acts of devotion went above and beyond the usual acts of brotherly behaviours. Growing up in a working-class family in St John's Wood, Eddie T.'s only brother Bill was 'more than a brother' to him. Bill was also a 'great friend' and 'champion' who 'took [Eddie's] part in everything'. This protection extended into Eddie's adolescence, which his brother supported him through 'with all the care and love of a boy'. ${ }^{157}$ While this statement implicitly acknowledges the gendering of caring roles in families, Eddie conveys the diligent tenderness exhibited by his brother. A desire to maintain 'face' led to Gordon S.'s refusal to escort his sister to a friend's party. His protective role was easily fulfilled by watching her safe arrival from a window. Never one to show his emotions, according to his sister, Gordon found other ways of displaying his affection: always giving her the 'best bite of the apple'. ${ }^{158}$ These small acts of solicitude undercut Gordon's emotional reticence, fostering an affectionate bond between brother and sister. 
Siblings adopted the role of protectors from an early age, frequently citing physical frailty or weakness as the reason why a brother might require additional protection. This was a deep-rooted expectation. John E. expressed relief that 'we didn't have a weakling in the family', having seen his friends' freedom curtailed by their 'attachment' to frail siblings. ${ }^{159}$ One of eight siblings, Elsie J. assumed most of the daily care of her brother, who was left severely disabled after a childhood attack of meningitis. Being tied down left her feeling bitter at times, especially when forced to miss out on leisure activities. Two of her brothers were 'undomesticated', unable or unwilling to help with routine chores or nursing. In contrast, Arthur, the youngest, would take over the full care of his sibling during his leave from the navy, his act of fraternal devotion giving his sister some much-needed respite. ${ }^{160}$

Janet Watson makes an admittedly generalised, class-based categorisation of wartime effort: whereas elites and the middle classes regarded it as 'service', the working classes viewed it as 'work'. A key difference between voluntary and auxiliary nurses and soldiers was the former's social obligation to consider their families' needs. Many middle-class families called on 'daughters at home' to prioritise familial duty, relinquishing their wartime duties if required or demanded to do so. ${ }^{161}$ Fraternal correspondence and appeals before the military service tribunals suggest that this expectation extended to 'sons at home'. When Private Joe Miller heard that his brother was anxious to join the Army Service Corps, he told him not to be silly, reminding him that it was his 'job' to look after their mother. ${ }^{162}$ In turn, tribunals expected siblings to pool business and familial responsibilities, performing intricate negotiations so that one or more might be free to serve. The wishes of 'sibling units' were often overridden by the need to maintain a steady flow of manpower to the front line. Nonetheless, the persistence and prevalence of these claims are indicative of the measured balancing of conflicting duties to family and nation.

Non-combatant and surviving brothers provided continuing support to the widows and children of brothers killed in action. Hints of the depth of feeling provoked by this fraternal duty are seen in the debate surrounding the call to amend the marriage laws to allow men to marry the widow of a brother killed in the 
war. ${ }^{163}$ Hard-line opponents argued that, as marriage created a 'real' brotherhood and sisterhood among in-laws, such marriages would be incestuous under canonical law. ${ }^{164}$ Proponents countered that the measure would legitimise the position of a significant number of widows living in 'irregular union' with their husband's brother. ${ }^{165}$ In March 1920, Viscountess Astor drew attention to the 'urgent need' to legalise such marriages to accommodate men eager to marry their brother's widow and care for her children. ${ }^{166}$ She received between 200 and 300 letters on this emotive subject. ${ }^{167}$ A 'conservative' estimate by The Woman's Leader put the number affected at approximately 2 per cent of the 240,000 women widowed in the United Kingdom. ${ }^{168}$ Widows writing in support cast themselves as 'victims' or 'sufferers'. Parliamentary debates concentrated on the loss of a breadwinner and the resulting fraternal desire 'to mitigate the privation and suffering' of the bereaved family, refocusing the discussion on the official recognition of gendered blood ties and responsibilities. ${ }^{169}$

\section{Reading wartime emotions}

Transcribing his wartime diaries in 1921, Arthur Wrench reflected on his journey to the Western Front, marking

[t]he beginning of those days of a thousand moods, flitting before our filmy visions like a phantasmagoria of hopes, fear, despair and passions, ugly shapes and beautiful ones calling on us, even voluntarily at times to join that vast army of souls who had already paid the supreme sacrifice, and then finally bidding us to 'keep smiling and carry on'. ${ }^{170}$

Wrench captures the uneasy juxtaposition of turbulent emotions masked by stoical behaviour. Even for emotionally articulate writers such as Wrench - a Scottish artist - capturing the full experience of trench warfare was difficult. ${ }^{171}$ Entering the world of wartime experiences is to encounter a maelstrom of heightened emotions. Mechanised conflict, combined with the relentless discomforts of trench warfare, imposed a heavy mental and physical burden on fighting men. Combatants experienced fear, anxiety, horror, dread, 
anger and grief. They bore the cumulative strain of enduring the 'constant traumatic witnessing' of comrades' deaths. ${ }^{172}$ Stresses invaded the domestic sphere, with family members bearing the protracted strain of anticipatory grief that was fuelled by the casualty lists filling the columns of local and national newspapers. Writing to her mother in May 1915, VAD Phyllis Puckle stated that the 'war gets more depressing every day'. Commenting that every casualty list seemed to have someone they knew on it, she wondered 'if there has ever been so much sorrow in the world before?" ${ }^{173}$ The absence of a body or grave heralded a period of hope mixed with dread. Over 200,000 bodies were never recovered. Families waited anxiously after receiving the stark notification, 'Regret - No Trace' - a state of limbo that brothers of the missing strove to rectify. ${ }^{174}$ An ambulance driver during the war, Joyce Hoskyns had 'been anxious to the verge of frenzy' for the four years following her younger brother's enlistment. On the date of his wounding in March 1918 she was out dancing when her partner asked her of his whereabouts. Despite her belief in 'the goodness of God', Joyce felt a premonition in the form of an 'icy hand on my heart'. ${ }^{175}$ The inescapable anxiety culminated in her bodily reaction to a long-anticipated death.

Emotions play a central role in historical research, particularly in studies delving into the intricacies of personal life. The identification of an 'emotional turn' has seen active engagement with the intellectual frameworks that we can employ to better understand the emotional lives of our subjects. ${ }^{176}$ Roper advocates using psychoanalytical tools to animate historical research, viewing it as a relational process in which the historian's subjectivity is inevitably engaged. By drawing on unconscious resources, as opposed to a discourse-focused approach, he argues that historians are better placed 'to imaginatively connect with the subjectivities of people in the past'. ${ }^{177}$ While acknowledging the necessity of a critical reading of personal testimony that seeks meanings below the surface, this study eschews the explicit use of psychoanalytical theories in favour of a wider, multidisciplinary approach. A 'peculiarly interdisciplinary' area, the history of emotions encompasses literary and religious studies, psychiatry, psychology, anthropology, sociology, philosophy and neuroscience. ${ }^{178}$ Our task is to negotiate the extremes between the universalism of theories and 
the specificity of family life and relationships. In his discussion of material culture, Daniel Miller observes that the less we are aware of everyday objects, 'the more powerfully they can determine our expectations, by setting the scene and ensuring appropriate behaviour, without being open to challenge'. ${ }^{179}$ A useful analogy can be made with emotional norms. Naomi Mitchison spoke of being 'netted by invisible rules' regarding ladylike behaviour. She was not 'taught' rules of behaviour, which she should have 'known by instinct'. ${ }^{180}$ Children learn what is expected of them in multifarious ways.

When examining wartime emotions, we must pay heed to the 'crude binary distinction' between self-control and self-expression. ${ }^{181}$ Although emotional life is far more complex than these polar opposites suggest, the dominance of masculine self-restraint in Edwardian public discourse is undeniable, shaping political and working-class sensibilities of masculine 'good character' and respectability. ${ }^{182}$ This code of manliness was taken seriously not only by pundits and preachers but also by young men. Conforming was an affirmation of their religious convictions and social aspirations. ${ }^{183}$ Self-control was deeply embedded in the ethos of 'Muscular Christianity' adopted by British public schools and cross-fertilised among working-class adolescents through sibling relationships and the 'character factories' of youth movements such as the Boys' Brigades, the Lads' Drill Association and Baden-Powell's Boy Scouts. ${ }^{184}$ Remnants of Victorian street culture, with its mindset of 'hard manliness' and emotional control, survived into adulthood. ${ }^{185}$ But, as has been observed in grief studies, working-class reticence and stoicism effectively disguise emotions, and we must seek out other expressive rituals and actions so as to fully understand the emotional experiences of war. ${ }^{186}$

Juxtaposed against this standard of manliness, as Stephanie Olsen convincingly shows, is the 'emotional consensus' instilled in boys and young men through informal moral education. Kindness and tolerance were valued sibling behaviours endorsed by Edwardian parents. The children of a Liverpudlian dairyman were brought up to be kind to their siblings. This mark of character defined the family ideology, summarised by the parental expectation that they be 'just a family'. ${ }^{187}$ Sympathy, caring and love in domestic 
life formed part of boys' 'emotional toolbox' in becoming a man. While not dismissing the power of normative expectations, we too often underestimate the cultural weight of 'felt' values instilled by familial culture. ${ }^{188}$ These quieter values, embedded in the warp and weave of everyday life, were part of the transition from boyhood to manly citizenship. Men caring for or cared for by brothers, brothers protecting or looking out for each other, boys and young men contributing to the household coffers, all understood and adhered to a wider code of domestic masculinity.

Parental strictures echo the guidance on manliness appearing in the periodical press and moral instruction books in the late Victorian and Edwardian era. Sibling love and sacrifice was idealised by moral tracts, becoming a 'measuring stick' for virtue. ${ }^{189}$ Moral instruction continued at school via daily biblical lessons and was further reinforced through Sunday school attendance and membership of the burgeoning mass youth organisations. Children's attendance at Sunday school remained high during the pre-war years, despite the decline in church-going among adults. ${ }^{190}$ There was some class disparity. A 1911 study suggested that only a fifth of working-class children in south London attended Sunday school. ${ }^{191}$ Entry to employment was a factor; the Sunday School Union estimated that 80 per cent of scholars were 'lost' to the church on attaining the 'working' age of fourteen or fifteen. ${ }^{192}$

Concerns about the spiritual education of this age group catalysed the growth of the 'brigade movements' aimed at attracting what the founder of the Boys' Brigade, Sir William Alexander Smith, termed the 'boy mind' to Christian manliness. One estimate suggests that 40 per cent of men born between 1901 and 1920 belonged to one of these organisations at some point in their lives. ${ }^{193}$ The interdenominational Boys' Brigade, set up in 1883, promoted the habits of reverence, discipline, self-respect and obedience - a masculine template replicated by its rival, the Anglican Church Lads' Brigade, established by Walter Mallock Gee in 1891. The founding principles of these brigades in turn influenced Lord BadenPowell's Scouting movement in $1908 .{ }^{194}$ Undoubtedly militaristic in outlook - a vital part of their appeal for working-class boys and young men - the movements' foundations were incontrovertibly moral and religious. ${ }^{195}$ 
Understanding how children and young people made sense of these diverse and sometimes contradictory emotional expectations, based on fragmentary glimpses into their life stories, requires a theoretical framework. Responding to the adult-focused underpinnings of histories of emotions, Karen Vallgårda, Kristine Alexander and Stephanie Olsen propose the concept of 'emotional formation'. ${ }^{196}$ This is both a pattern of emotional structures and a reiterated process cultivating codes of feeling through informal education and repeated daily experiences and practices. This approach stresses the contingency of feelings but does not explicitly acknowledge the role of siblings and lateral bonds in helping children and young people to mediate emotional norms as they are applied in differing situations.

Influenced by his critical reading of cognitive psychology and neuroscience research, William Reddy developed the concept of emotional regimes to explain how emotions can act as agents of historical change. Regimes comprise both the complex set of practices establishing emotional norms and the sanctions for those who break them. ${ }^{197}$ This penalising authority lends regimes their social and political power. In the distinctive climate of world conflict, this concept has some attraction as a model against which to view codes of feeling, values and behaviours, assisting our appreciation of how the Great War marked a watershed moment in the evolution of a culture of emotional repression. A patriotic discourse bolstered acquiescence with state management of military and civilian emotions. Exceptional times made compliance essential to the functioning of wartime society. ${ }^{198}$ Observance of the codes underpinning the suppression of prescribed feelings required great effort by individuals. Self-restraint was lauded in both military and civilian life. Societal attitudes valorised stoicism and patriotic loyalty over the expression of personal emotions, especially grief. In August 1914, the archbishop of Canterbury called for 'natural' emotions to be held in check, stressing that steadfast self-control was not merely desirable but 'sacredly imperative'. ${ }^{199}$ Vera Brittain hinted at the effort behind such containment in the run-up to the Battle of Loos in September 1915. An 'anxious stillness' descended on the country, 'making everyone taut and breathless'. ${ }^{200}$ Yet, of all the 'templates of emotional control' playing a formative role in 
developing a culture of self-restraint, the armed services presented the most familiar standard. Soldiers' repression of emotions in the most harrowing of circumstances was widely admired. Mentions in despatches recorded in the Edinburgh and London Gazettes contain frequent references to coolness and 'cool leadership', the antithesis of heated, uncontrolled passions. ${ }^{201}$ As more subscribed to the logic of this emotional norm, wartime behaviours entered into a feedback loop. When regimes reach a coherent structure, conforming becomes defining for the individual. This 'cultural exaltation' of particular forms of masculinity, such as the soldier-hero, becomes problematic when the 'pressure of conformity' pushes out alternative narratives such as male or sibling grief. ${ }^{202}$ Florence Lockwood, grieving for her nephews, experienced a disenfranchisement of her grief. Among the mass bereavement, her auntly bond with them was deemed insufficiently close in the hierarchy of mourning. ${ }^{203}$

Barbara Rosenwein claims that Reddy's highly regimented model sits uncomfortably with the complexities of modern society. ${ }^{204} \mathrm{Her}$ concept of emotional communities, encompassing inter alia families and neighbourhoods, adopts the device of 'not entirely concentric circles' to explain how individuals move easily between emotional communities, provided that the underlying norms are not radically different. ${ }^{205}$ Individuals' emotional styles are dependent on context, altering within families, among friends, at the workplace or in the army. This fluidity facilitates the mediation of the dominant wartime regime of patriotic sacrifice by familial values and priorities. ${ }^{206}$ Sara Ahmed's consideration of 'influence' is a useful addition to this framework. Within the family and other emotional communities, it is often easier to see the prohibitions rather than the affirmations of behaviour. Seeking out these 'invisible' points of pressure informs our understanding of the cultivation of familial and societal norms. ${ }^{207}$

Neither Reddy nor Rosenwein fully addresses what happens at the emotional intersections of regime, emotional community and individual feeling when respect for familial or communal bonds takes precedence over the state management of emotion. ${ }^{208}$ Familial codes infiltrated the front line and other areas of wartime life. Despite the differences engendered by class, religion and place, there was a remarkable commonality in these norms. ${ }^{209}$ Focusing 
on sibling and familial values and practices helps us to understand the wartime patriotism of a combatant like Sapper Frank Day, who served with the Royal Engineers in Egypt and Palestine. Like many serving men, he supported conscription, believing an influx of single men of fighting age would end the war sooner. He disparaged conscientious objectors and the 'slackers' on the docks near his training camp. ${ }^{210}$ Yet, Day hoped that his younger brother would not experience combat, advising his parents to 'tell John he must not join until he is old enough'. When it was confirmed that his sibling had secured a continuing exemption due to his munitions work, he was 'very glad', telling his brother to 'keep out of the army as long as ever you can'. ${ }^{211}$ Day upheld two contradictory positions regarding the service of young single men, both with their own consistent logic. Patriotic acceptance informed his acceptance of the necessity of military service. His experience of military training and combat informed his desire that his younger brother be spared. By focusing on such individual moments of transgression or conflict, we can appreciate the elasticity of emotional norms at regime, community, family and sibling level.

Not all lapses of wartime emotional codes were met by draconian responses. Experiential evidence strongly suggests that it is the compassionate policing of regimes that cements adherence, through a dual process of rewarding emotional effort and recognising emotional fragility in times of extreme stress. Vera Brittain provides a rare autobiographical account of a reprimand. One of her friends scolded her 'difficult' demeanour following the death of Roland Leighton. ${ }^{212}$ Many instances of emotional 'breaches' appear without condemnation in men's narratives. Tolerance of 'deviant' behaviour, argues Helen Smith, was largely based on the appropriate demonstration of manly conduct or good character in the workplace and home. ${ }^{213}$ Adherence to societal codes and values garners individuals respect from superiors and peers. Such respect grants limited freedom of expression, especially when that expression speaks to an accepted cultural or emotional convention in a particular community. This premise of compassionate enforcement builds on Reddy's 'emotional refuges' - a space, understanding or ritual providing safe release from prevailing norms - by unpicking the conditions under which such 'understandings' are made. ${ }^{214}$ 
The community and the individual traverse these instances of heightened emotional states in a way that supports both the regime and its members.

Within the emotional regime of the fighting unit, individual reputations rested both on men's past actions and on conformity to emotional norms. ${ }^{215}$ Unfettered emotions were dangerous. Quiet strength, discipline and courage were vital masculine traits enabling men to remain functional in the midst of fear. ${ }^{216}$ Mastery depended on effort and control, instilled by practice. ${ }^{217}$ Officers, in positions of authority, retained the locus of control, part of the acceptance of military authority by rankers. Consequently, young officers feared breaking down in front of their men. Focus on the officer classes has marginalised the routine restraint practised by subordinates. ${ }^{218}$ The end result was a shared ethic of endurance. ${ }^{219}$ This code was underpinned by quieter, empathetic values, one war memoir alone recording eleven examples of kindness. ${ }^{220}$ The comrades of Fred Cearns ascribed his popularity not to the 'false bluster of a bully' but to his sympathetic and kind demeanour and actions. ${ }^{221}$ The cultural respect for fraternal ties is apparent in the consideration offered to anxious or grieving brothers. When nineteen-year-old Gilbert Hosegood learned of his brother Arnold's death via an announcement in The Times, he was 'sustained by the kindness of his friends'.222 This cut across class, with kind solicitude being proffered by rankers and officers alike. Missing the companionship of his brother Dodo, Tom Baines praised the thoughtfulness of his 'rough men' who demonstrated practical support by their efforts to lighten his load by carrying out some of his duties. ${ }^{223}$ Deaths of brothers seem to have transcended the anonymity of mass casualties, affecting not only surviving siblings but also combatants witnessing the trauma resulting from fraternal mortalities. Rarely were men castigated for post-battle displays of emotion. Informing this reaction was knowledge of wartime conditions and the resulting loss of privacy - a loss remarked upon by Vera Brittain, attempting to shield her tear-stained face during a routine inspection of her VAD quarters. ${ }^{224}$

Men's awareness of the need for control in combat led them to seek private spaces to vent emotions, a behavioural pattern likely to garner respect from their peers. ${ }^{225}$ Tears are a sign of complex 
emotions, expressed on a spectrum of intensity and control.226 Against the turbulence of battlefield emotions, abstract distinctions such as the romantic view that the most profound grief is tearless did not match the daily realities of trench warfare. ${ }^{227}$ The opening up of vulnerability, combined with the viscerality of weeping or sobbing, made it a discomforting experience for observers. Seventeen months after Arnold's death, Gilbert Hosegood received the devastating news that his other brother had been killed in action. He left his billet 'blinded by tears and in silence', his close friend respecting his desire for solitude. ${ }^{228}$ A code of silence preserved the privacy of such 'sacrosanct' outpourings. Soldiers on leave sought refuge in the privacy of the theatre or cinema, where tears could be shed in relative privacy. ${ }^{229}$ Paying greater attention to these moments and spaces of grief challenges the presumption of wartime stoicism and invites the historian to seek them out. It begs the question of how we can fully understand the adoption of the stiff upper lip across class and gender without a full exploration of these nuanced negotiations of public and private behavioural codes. ${ }^{230}$

\section{Brotherly loss}

Grief permeates many of the narratives examined in this study. Like the working-class autobiographies studied by David Vincent, 'bereavement is everywhere'. ${ }^{231}$ The scale of casualties during the First World War, amounting to approximately three-quarters of a million British servicemen, created a seismic shift in attitudes to death and mourning, breaking the liminal nature of communal mourning in times of tragedy. ${ }^{232}$ Uniformity of grief and the experience of trench warfare led to a narrowing of experience across classes and regions. ${ }^{233}$ Veterans and civilians alike struggled with balancing the desire to forget and to resume their lives with the recognition that such experiences should not be forgotten. ${ }^{234}$ Rightly affirming the deep and lasting effect of sibling separations and deaths on surviving siblings, Leonore Davidoff's claim that the resulting emotional deprivation increased with the advent of the nuclear family contradicts her earlier finding regarding the particular closeness of sibling groupings in larger families. Her consideration of fraternal 
grief is focused on historian E. P. Thompson's portraying the death of his brother, Frank, in the Second World War as a 'defining' influence. This insight is fundamentally weakened by a failure to analyse sibling loss from the perspective of surviving brothers in the Great War, compounded by Davidoff's close examination of the often cataclysmic consequences of brotherly loss on surviving sisters. ${ }^{235}$ This imbalance restricts our appreciation of the significance of sibling relationships in wartime and how experiences of sibling loss fed into shifting patterns of grief and mourning throughout the twentieth century.

The focus on public commemoration after the First World War meant that the war dead remained a collective presence in people's lives. Post 1918, a culture of forgetting and silence overlaid emotional responses to death. Growing up in the Calder Valley in the aftermath of the Great War, the poet Ted Hughes recalled how the whole country was 'traumatised'. ${ }^{236}$ Many families preferred not to talk about the war. Yet this blanket of silence was unsuccessful in masking underlying pain. Bodily scars or missing limbs were physical reminders of the war's legacy. Photographs and shrines to loved ones, artefacts including medals and service papers, and trench art became assimilated into households. The fallen were known individuals in their local communities - at household, street, neighbourhood and parish level. Particular locations held emotional significance. One of two survivors of his cohort of eight scholars, Harold Macmillan could not face returning to Oxford. It would simply be too much to return to this 'city of ghosts'. ${ }^{237}$ The author Henry Yorke, writing under the pseudonym Henry Green, cautioned that his generation might have exaggerated the feeling of death being 'all about us'; a belief that was reinforced by the act of 'going over and over it' after the war ended. Nonetheless, the actual experience of death, such as that of his brother Philip, 'brought death close enough' to those, like him, too young to fight. ${ }^{238}$

Influential studies of death and mourning by Geoffrey Gorer and Phillipe Ariès propagated the belief that the post-war years saw the bereaved 'hiding' their emotions, a response to the growing social expectation that grief should be contained. ${ }^{239}$ This trend became entrenched as the twentieth century progressed, bolstered by the 
medicalisation of death and incremental adoption of cremation. Tracing the emergence of a culture of emotional repression, Pat Jalland pinpoints the Second World War, and the mass experience of the Blitz, as marking 'a profound break with the past'. ${ }^{240}$ By the end of the Second World War, Gorer proclaimed, death had replaced sex as the new social taboo. ${ }^{241}$ Documenting experiences about which people do not speak is always testing, but even during this period of 'disallowed' mourning, Gorer and other researchers recorded individual accounts of emotional loss. ${ }^{242}$ A question mark must surely be raised over our full appreciation of this chronology of grief when male and sibling grief is consistently overlooked.

\section{Memory keeping}

Public memories of the Great War drown out private, more intimate memories. The scale of Great War casualties is almost unimaginable to comprehend. Bodies of dead soldiers became 'official' property, buried alongside their comrades in military cemeteries. Individual names became subsumed in the mass of losses. This anonymisation of the dead explains siblings' compulsion to mark the particular war stories and sacrifice of brothers, salvaging individual stories from the incomprehension of mass slaughter. The cultural focus on the war dead has obscured the experiences of men returning home from the front. Sibling memoirs provide a medium where the stories of both converge to present a fuller picture of men's wartime service and its aftermath.

Sixty years after John Campbell wrote a six-page account of Percy's death, Pat retraced his father's steps when writing his own fraternal memorial. The youngest of three, Pat was seventeen when war broke out, three years younger than Percy. His memoir is a multilayered narrative of public and private memories and commemoration, filtered through a lens of fraternal love and grief. Having fought in and survived the war, married, brought up three children (naming the eldest after Percy) and enjoyed a successful career, Pat was reflecting on a lifetime of absence when he embarked on his act of fraternal memory keeping. His perspective is that of an older man looking back at his younger self. ${ }^{243}$ 
His act of memorial writing formed part of a more extensive effort by Pat to record his wartime experiences. After his retirement as master of Westminster Under School, ${ }^{244}$ perhaps prompted by the 1960s memory boom and the desire of ageing veterans to record their experiences, he went on to write three books in the 1970s and 1980s. The first two covered his war experiences. His final book, published in 1986, the same year as his death at the age of 88 , was his autobiography 'of an ordinary man'. ${ }^{245}$ Before embarking on this series of life-storying, he 'had two debts to pay'. ${ }^{246}$ The first was to tell the story of his brother Percy, and the second to do the same on behalf of a family friend, [George] Leonard Cheesman, who had been killed in action at Gallipoli in August 1915. Notably, Pat ring-fenced these intimate memories, omitting them from his published autobiographical works. His placing of both in public archives suggests his belief that these were vested with historical value and should be preserved, in Percy's case, as part of a more official record of the war. This was not the only memorial to Percy Campbell. As a prime example of the layering of memory within communities of mourning holding significance to the fallen, Percy's name appeared on the memorials at Dragon School; Hertford College, where he studied medicine; St Ebbe's church, Oxford, where he taught Sunday school; and the Menin Gate, Ypres monument to the missing.

Safekeeping the memory of brothers and their sacrifice is a recurring motif in many memoirs, a final act of devotion. In the process, they perform a valuable function of war writing: that of revealing and recording love. ${ }^{247}$ Examining the interplay of fraternal relationships as related in men's memoirs facilitates the mapping of fluctuations in emotional expression over time. Recent studies of post-traumatic stress have revealed the persistence and force of some emotions. The durability of these felt reactions, their management by the state and the adopted 'choice' to forget combine to create a complex palette of memory, experience and brotherly interactions. Within men's narratives we see a subversion of codes of silence. Adherence to codes of manly behaviour, and their desire for emotional privacy, meant that strong and unsettling emotions often remained hidden from public view. But sometimes grief proved 
too strong to be contained successfully. Men and women wrote publicly about the depth of their loss in successive months, years and decades. Winter adopts the notion of 'communicative silence' to explain the transmission, within families, of messages about distressing or traumatic events which everyone knows about but never speaks. While such tacit communications can bond families, Winter highlights the importance of 'silence-breakers' who communicate these messages outside family boundaries to apprise later generations of the personal ravages of war. ${ }^{248}$ Brothers in the Great War shows how fraternal acts of memory keeping deliberately sought to place intimate loss in the public sphere.

\section{Sources}

Brothers in the Great War draws on a wide range of contemporary and retrospective sources. Letters between brothers in the early twentieth century have not been used before as the primary focus of study, and are supplemented by diaries, oral interviews, published and unpublished memoirs, poetry and prose, and local and national newspapers. Personal narratives have been selected when they include writings between or about brothers and sisters from the same family. Archives of personal papers held by the Imperial War Museum and the Liddle Collection at the University of Leeds hold collections of familial correspondence from all classes and regions. Setting these apart from other collections is the intermingling of correspondence with war-specific items such as photographs of uniformed brothers, service records and medals, letters on Young Men's Christian Association (YMCA) headed paper, field postcards and green envelopes. ${ }^{249}$ Inescapably, we are examining lives through a wartime filter. Feminist historians have argued that the attention focused on fighting men effectively excludes the private, unofficial stories of women from the collective memory. ${ }^{250}$ The same charge may be levelled against the 'silencing' of non-combatant men those too young or too old to fight, or those exempted from service. Inhabiting the worlds of both home and fighting fronts, sibling narratives present a lateral perspective of the lived experiences of the war generation. 
Encompassing a diverse range of sources counters the inherent bias of particular genres of texts, such as letters of condolence, and the relative scarcity of some source material. The gendered bias of wartime correspondence means that there are fewer extant letters between male family members in the archive. ${ }^{251}$ While acknowledging the maternal role of family gatekeeper, considerations of the emotional sustenance garnered from specific familial bonds during wartime must take account of the archival bias against young men of serving age. Writing and preserving letters was difficult for combatants. Men more commonly kept letters from sweethearts and wives. Retention is not the sole marker of worth; unpreserved letters were still highly valued. ${ }^{252}$ The absence of working-class voices is partially redressed by the inclusion of oral interviews and the spate of published accounts that appeared towards the end of the twentieth century. Official records provide useful testimony; 'coerced' narratives can, argues Carolyn Steedman, offer a distinct form of life stories. ${ }^{253}$ Lastly, the range of sources reflects the book's structure. Oral interviews flesh out the childhoods of the war generation; contemporary letters and diaries reveal patterns of familial and emotional wartime behaviours; and retrospective memoirs expand the temporal boundaries of the war years, essential when exploring sibling grief and memory keeping.

People living through the war years were aware that they were engaged in the act of making history. ${ }^{254}$ In August 1917, Willie Baines seeded the idea of commencing a history of the war as it affected the Baines family, believing that it would be of 'absorbing interest'. ${ }^{255}$ Even contemporary recorders such as letter writers and diarists, ostensibly writing for themselves or to family members, wrote with an eye to informing future generations. ${ }^{256}$ Boots the Chemists appealed to this predilection. Advertisements for its $6 \mathrm{~d}$ pocket diary were headlined, 'Keep a Diary of the Historic Year, 1915'. They were sized to slip easily into a rucksack; combatants could jot down 'priceless notes' of their adventures, producing a record to 'value all [their] life'. ${ }^{257}$ The artist and suffragist Florence Lockwood maintained a detailed diary throughout the war years; her chosen title, Sign of the Times, was a nod to the momentous events she recorded. An amalgam of diary entries and newspaper clippings, it was an active document, dotted with approving or 
disapproving comments, the dates of key events and a list of the service records of her cousins and nephews. She regularly annotated the latter with dates of woundings and deaths. ${ }^{258}$ The year 1917 saw Captain Ernest Hewish languishing on the home front, based at Herne Bay. Ready to abandon his diary keeping, he recommenced when a number of incidents convinced him that he would have no trouble finding 'copy'. This optimism proved short lived as Hewish expressed his frustration at merely providing a 'chronological record of the big events' rather than his 'personal feelings \& experiences' ${ }^{259}$ Hewish felt diminished by his geographical and emotional distance from front-line fighting.

Inevitably, highly literate personal narratives dominate personal histories of war. Working-class narratives should not be dismissed for lack of erudition. Progress initiated by the 1870 Education Act, together with the work done in elementary and Sunday schools created a remarkably literate working class by the turn of the century. In 1871 an amendment to the Revised Code governing the school curriculum included the composition of short letters, ensuring that, by 1914, the majority of fighting men possessed rudimentary letter-writing skills. The burgeoning mass market in popular fiction, coupled with greater accessibility of books through cheap editions and lending libraries, meant that the vocabulary of many working-class people was richer than is often appreciated. ${ }^{260}$ Rather than disparaging the clichéd, we should acknowledge its normative value as a tool of reassurance for both sender and recipient. Glimpses of writing skills emerge from letters sent by much younger siblings to their soldier-brothers. Eight-year-old Anthony Wilkinson, born the son of a coal miner in County Durham, sent his brother a letter which shows some comprehension of letter-writing conventions:

Hoping you are well. What are you wanting the chronicle [sic] for. I want it to learn a poetry out of. It is a very windy day to-day ... I wish you would come home. ${ }^{261}$

This missive, complete with a drawing of a 'brave soldier' wielding a gun and ending with eleven kisses, contains unexpectedly rich information about the circulation of discourses on heroic sacrifice, requests for reading materials, the conventions of asking 
after the health of the recipient and a plaintive expression of sibling separation.

Some men were self-critical of their literacy. 'I am the poorest letter writer among mankind,' declared Ray Turner, a former hairdresser, to his sister Grace. Even mundane correspondence reveals fraternal affection and shifts in tone, marking anxiety, fear or relief. At the end of a letter informing Grace of a planned operation to remove two pieces of shrapnel from his leg, Ray closed with a reassuring touch of humour, using his 'French name' Raymonde. ${ }^{262}$ The middle and upper classes highly valued letter-writing skills. Cecil Falk upbraided his youngest brother, Eric, threatening to ignore future letters if his 'disgraceful' handwriting did not improve. ${ }^{263}$ When this went unheeded, Cecil, determined to ensure his brother met the standards of 'a public school man', warned Eric that 'you really must improve or have lessons ... \& I shall write \& tell Father so too'. ${ }^{264}$

\section{Contemporary sources}

The emphasis on the present, the events of a single day or days, distinguishes letters and diaries from other narrative sources. ${ }^{265}$ This immediacy confers an innocence of what the future holds, ensuring that they are untainted by hindsight. ${ }^{266}$ Although they are 'private' texts, both of these narrative forms follow public conventions of expression. This attribute, according to Stephen Stowe, imbues them as spaces where people could 'embrace and resist the time and place in which they lived'. ${ }^{267}$ As such, they furnish invaluable insight into the negotiation of conflicting emotional codes by serving and non-combatant men. Letters and diary entries, especially those with emotional significance, could be the result of careful craftwork, belying their supposed immediacy. Alan Bishop, editing Vera Brittain's diaries, noted that she drafted the poignant entry detailing her receipt of the news of Roland's death several days later. ${ }^{268}$ Such acts of composure are usually hidden from view.

Both letters and diaries are frequently reproduced within war memoirs, purportedly representing a 'truthful' account of events. The writer and the reader gain access to two voices: one belonging 
to the individual living through the experience and the one belonging to his or her reflective older self. ${ }^{269}$ Vera Brittain believed her 'crude and ingenuous' contemporary opinions to be as important a record of her wartime experiences as her knowledge-laden retrospective reflections. ${ }^{270}$ Arthur Wrench declared that his war diary was neither a story nor a history of the war. Instead, it represented something 'essentially personal'. ${ }^{271}$ A further example of the crosspollination of source material is found in the 1915 diary kept by Alf Arnold. Falling into the category of diary writers who kept minimal, factual records, Arnold assiduously recorded letters received from, and sent to, his brothers. ${ }^{272}$ Such actions were a means of imposing order over troubling emotions. ${ }^{273}$ Similarly, the thirst for information led to siblings demanding and supplying detailed accounts of daily routines and environments, almost turning letters into quasi-diaries. ${ }^{274}$

Jessica Meyer suggests that a key difference between letters and diaries is the rarity with which home appears in the latter. ${ }^{275}$ Offsetting this viewpoint are journal entries recording the receipt of family correspondence, and key dates such as birthdays and anniversaries. Thoughts of home and siblings crept into the most factual of diaries. The war diaries of Edith Appleton focus predominantly on her experiences as a nursing sister in northern France. She meticulously began the entries falling on her siblings' birthdays by wishing them 'many happies'. ${ }^{276}$ A different pen indicates that Signaller Henry Allot marked up his sibling birthdays in advance, ensuring that he did not forget to send a celebratory letter or card. ${ }^{277}$

Absences in archival and edited collections may be the result of familial sensitivities or a view that domestic matters did not fit into a war narrative of perceived wider public interest. Other omissions are less clear cut. The extensive familial correspondence of William Stoddart includes letters sent and received by his parents and cousins. Despite his writing to his mother, father and sister Bertha 'in turn', the letters to Bertha are missing, indicating that these were preserved, or perhaps disposed of, separately. ${ }^{278}$ Without any context, we are left to surmise why there are gaps or omissions in collections. The preservation or archiving of the single 'last letter home' of a soldier-brother is understandable, comparable, perhaps, to the Imperial War Museum's project to collect and display 
photographs of the fallen. ${ }^{279}$ Some families retained originals, while sharing individual stories with a wider audience. Edited collections deny us the object's materiality, omitting vital signs that are of interest to historians of the emotions and the family - not only intimate family matters but also paratexts indicating emotional states such as lapses in routines, abrupt changes of subjects, slips of the pen, crossings-out, underlinings, postscripts, doodles, changes in handwriting and sign-offs and multiple kisses. ${ }^{280}$ The materiality of letters offers clues as to their meaningfulness to recipients. These physical artefacts, Martha Hanna asserts, fostered intimacy by evoking the palpable presence of the writer. ${ }^{281}$ Deep creases are poignant indicators of how letters were poured over to extract precious information about loved ones. John Skellern wrote a brief, one-page letter to his wounded brother Isaac. ${ }^{282}$ The deep scores along the fold lines indicate that this was much read by Isaac, who remained in hospital until his medical discharge just under a year later.

Preserving and editing letters were acts of emotional labour and memory keeping. Joe Miller undertook the task of transcribing and annotating the thirty-one letters sent home by his brother William, as an avuncular act of memory-keeping for his nephews, perpetuating his brother's war story. ${ }^{283}$ Relational bias was created not only by authorship but also by choice of content. When writing his memoir of the 'rich and strenuous' life of his son Paul, Harry Jones, editor of the Weekly Sun, included over eighty edited letters written by Paul. Eight of these were addressed to Paul's younger brother, Harry Victor, who, like Paul before him, was a pupil at Dulwich. ${ }^{284}$ Jones senior wove this correspondence into his patriotic narrative of the war's influence on the mind of a public-school boy. The volume starts and ends with a letter sent to Harry Victor. Through this authorial device, the ultimate sacrifice made by Paul is seen to exert an inspirational pull on his younger sibling.

Personal papers and narratives offer information about material and commemorative objects that is otherwise hidden from the historical record. VAD Olive Dent recorded the subjects of the three photographs that fell out of a patient's paybook: his parents in their Sunday best; his 'girl', a munitions worker; and an elder brother, a gunner. ${ }^{285}$ Sibling letters record the exchange 
of souvenirs, postcards and photographs between siblings. Images provoked emotional reactions. Thanking his younger brother, Ged, for sending him a portrait of himself in uniform, Reginald Harvey added his fervent wish that 'this murderous business' be over before Ged reached the age of nineteen, thence becoming eligible for overseas service. ${ }^{286}$ Pictorial representations took on a poignancy when used to record the graves of dead siblings. Uncertain, Douglas Heaton verified that the cross on the photograph sent to him by his mother appeared to mark his brother's grave. ${ }^{287}$

A letter from home, stated Private Tom Povey, 'is as good as a parcel'. Wanting to ensure a regular supply, Povey asked his working-class siblings to stagger their letter writing so that he received mail on separate days. ${ }^{288}$ Soldiers were avid letter writers, an activity facilitated by the immense postal infrastructure. Previous conflicts highlighted the role of letter writing in maintaining morale. ${ }^{289}$ The Army Post Office Corps, a special reserve unit of the Royal Engineers, was mobilised within days of the outbreak of war in August 1914. ${ }^{290}$ Over 12.5 million letters a week were sent home, and 'for practically every letter sent to the front a letter came home'. The level of parcels sent out to the front was prodigious, peaking in the four weeks prior to Christmas 1916 with 4,600,000 dispatched to the British Expeditionary Force alone. ${ }^{291}$ Standard multi-choice field postcards offered time-pressed, wounded or illiterate men the opportunity to disclose essential news about their wellbeing. Millions were sent, particularly after battle. Men often went into perilous situations with one prepared in advance. ${ }^{292}$ Commentators have dismissed these forms as prosaic, providing little information apart from 'signs of life', and have overlooked their emotional value for recipients which is suggested by their ubiquitous presence in the archives. ${ }^{293}$

Censorship rules prohibiting information about logistics and details of military action bound those serving in the ranks. In practice, the administration of censorship was patchy at best. Officers, trusted to censor themselves, frequently abused this privilege. Families drew up 'codes' to signpost the whereabouts of fighting men. Scrutiny wavered under the sheer volume of post and the uneven exercise of subjective judgement. Consequently, letters home contained candid reports about combatants' experiences. ${ }^{294}$ 
More impactful than official censorship were emotional conventions bounding the extent to which combatants shared or concealed the realities of warfare. ${ }^{295}$

While not specifically banned as a practice by army regulations, serving men were prohibited from keeping any information on them that might assist the enemy if they were captured. Combatants like Private Arthur Wrench, determined to capture their experiences, resorted to writing clandestinely and using abbreviations intelligible only to themselves. Portable and inconspicuous pocket diaries are prevalent in the archives, a practical solution for many wanting to keep their kit-bag's weight to a minimum. Established in 1896, Charles Letts the stationers were quick to capitalise on this new market. In 1914 they introduced a new addition to their range for 1915. The Soldier's Own Diary came complete with an EnglishFrench phrasebook, for the cost of one shilling. Two years later the company collaborated with the British Red Cross to produce a diary aimed at nurses and VADs. ${ }^{296}$ The compressed form of these diaries in turn shaped diary entries. The condensing information into the small space allocated to each day lent itself to concision and the repetition of information such as the weather.

Writing letters is a relational act, a vital means of articulating and maintaining relationships at a distance. ${ }^{297}$ Comprehending the essence of these ties requires attention to be paid to the writer's age, gender, his or her place and role within the home and the intended recipient and wider readership. Often seeing only one side of the conversation, we can surmise the questions or concerns prompting specific responses. Family members poured over letters, alive to shifts in tone. Sustained correspondence took place between brothers and these letters were greatly appreciated. Jack Tavernor wrote at least every three to four days to his brother Will. Even when circumstances made this difficult, he strove to write at 'every possible chance'. ${ }^{298}$ Letters were private spaces where brothers exchanged confidences. As will be seen in Chapter 3, they provided a space where brothers shared their emotional response to their wartime experiences. Regular correspondence did not alleviate the wearing anxiety experienced on both fronts. Speaking of the average four-day delay in the receipt of letters from the Western Front, Vera Brittain, the chronicler of sibling grief and anxiety, 
observed that this was ample time for loved ones to die 'over and over again'. ${ }^{299}$

Conditions of military service were often unconducive to letter writing. Occasionally correspondence was interrupted by a shortage of writing material. Kit-bags could not accommodate non-essential supplies. Men resorted to writing on scraps or borrowed sheets of paper. ${ }^{300}$ More frequently, communications were disrupted by periods of active combat. Sam Goodman constantly reassured his older brother Abe that the absence of letters did not signify bad news but reflected the 'utter impossibility' of writing home. In December 1916 he cautioned his brother not to be anxious. It was almost impossible to get letters through his part of the line, formed of 'shellholes linked together'. ${ }^{301}$ John Pearce appreciated that news reports of fighting would arouse anxiety. He was swift to scribble a note to confirm that he was 'safe and well' despite things being 'all upside down' after the Germans launched their spring offensive in 1918. ${ }^{302}$ Communicating by letter, with sometimes unpredictable delays, led to sibling misunderstandings. The thirty-seven letters and postcards sent home by Sapper Jim Sams to his sister Maud in Hackney represented a weekly ritual; both had a set day for writing. Any disruptions caused 'upset' to Jim, reliant as he was on this link to home. After one threeweek gap, he wrote apologising, troubled that his sister was annoyed by his request that she should write to their brother, Tom,

Is there anything wrong at home if so please let me know. I hope you have not got offended ... if so please put it on one side and forget it, I almost wish that I had never wrote it has it seem [sic] if he has forgotten me for I have not heard from him for a month. ${ }^{303}$

The routine of correspondence, the writing down of the experiences of trench combat, could be onerous for serving men. After six months' active service, Bertram Evers was 'in no mood for letter writing'. It was not that he was depressed, he assured his brother, rather that 'letter writing is one of those acts of peace \& quiet not of jumble $\&$ strife'. ${ }^{304}$ Appreciating the weight of this expectation, brothers alleviated this, telling siblings that they were not obliged to write or reply to letters. In this respect, this study disagrees with Jenny Hartley's assertion that such statements show the low expectations of men as letter writers. ${ }^{305}$ Rather, it was an appreciation of 
the difficulties of maintaining regular patterns of correspondence in the midst of battle or placing an additional burden on combatants during periods of respite. Quiescence, Annette Atkins observes, was characteristic of sibling relationships, with intimacy readily restored when contact was resumed. ${ }^{306}$ When family information was being relayed by other family members, it was harder to find newsworthy items to fill letters. ${ }^{307}$ As one of the functions of wartime letter writing was to dispel the anxieties of loved ones waiting for news at home, by obviating the need to respond brothers lifted this particular wartime duty.

\section{Sibling confidences}

Reading letters was widely understood to be a communal practice. ${ }^{308}$ In the absence of reciprocal voices within the correspondence, practices of sharing offer valuable insight into the emotional reach of missives. The personal papers of Edwin and Tom Alcock shows the seriousness with which this was undertaken. Annotations mark the letters read by Edwin's twin brother, Harold, and a list of extended recipients recorded on each envelope, ensuring that any disruptions to their efficient circulation were noted. ${ }^{309}$ Siblings addressed sections of letters to specific family members or explicitly asked for certain news to be disseminated or withheld. About to be sent over to France, Tom Povey asked his sister to withhold this information from Ma. ${ }^{310}$ Reviewing patterns of self-censorship in the familial community of emotion reveals the elaborate interplay of intra-familial support and protection. Significantly, we see how the epistolary 'self' presented to the communal family differed from that appearing in letters addressed to specific correspondents. Martha Hanna states that combatants endured the miseries of trench warfare precisely because they wanted to protect their womenfolk, especially mothers, from its full brutality. ${ }^{311}$ Siblings were more likely to receive 'uncensored' correspondence. Withholding distressing information from parents was a practice rooted in childhood. When Jack Haldane's arm was broken during a bullying incident at Eton, his sister contrived with him to conceal the circumstances of his injury. Under the cover of manly behaviour, 
siblings of both sexes assimilated an emotional code of restraint and deception. ${ }^{312}$

The view that sisters were the most common recipients of graphic accounts of combat fails to specifically address the content of letters sent to brothers, reinforcing the inherent gender bias of archival material mentioned earlier. ${ }^{313}$ Analysis of brother-brother correspondence demonstrates that letters served as an outlet for frank portrayals of trench warfare. After his promotion to sergeant, Alec Mudie wrote a postcard to his younger brother, the manager of a public house in London. His vivid account of conditions is unsparing in its brevity:

The weather out here is awful snow hail rain \& MUD. In the trenches we get smothered from head to foot with wet or frozen mud. At one lot I had 18 inches of water with $1 \frac{1}{2}$ inches of ice on top ... I was hit on the head with a small piece of shell but it only raised a big bump and gave me a headache. ${ }^{314}$

Comparing this to a letter sent by a fellow Londoner, Arthur Hubbard, to his sisters, we see a similar approach to relaying the grim realities of trench life:

I shall imagine I am in heaven when I get home, what a treat it will be to feel nice and clean, at present it is up to your neck in mud which all helps to make you feel miserable.

Apologising for his frankness, Hubbard is disinclined to tell his siblings 'a pack of lies', believing that if the truth were told more often the war would be over sooner. ${ }^{315}$

Mothers were singled out as requiring particular protection from more gruesome details of modern warfare and the imminence of combat. Trench warfare, Major Sidney Baker told his brother, is 'one long degradation'. Unsparing in his account of assisting casualties, he added that 'this is hardly a letter to show mother. I think she is worrying more this time than before. ${ }^{316}$ Brothers reinforced this convention. In September 1916, Harold Round informed his mother of his part in 'a colossal push' the next day. ${ }^{317}$ His older brother, Murray, rebuked him for this 'unwise' missive. Returning home on leave he found 'everybody in a nervous \& worried state'. Murray stepped in to provide guidance, advising his brother that 
it was preferable 'to mention these things after you have finished the show'. ${ }^{318}$ Siblings did not share sensibilities over the conveyance of war news. Charles Gee was annoyed over his brother's 'lurid' descriptions of his experiences on the Somme. In his view, these letters drove their ailing mother 'off her rocker'; 'I mean one oughtn't to write them', he added. ${ }^{319}$ With reports of offensives appearing in the national and regional press and circulated via informal networks, the effectiveness of such strictures was limited. At times of high familial anxiety over men's wellbeing, the frequency of correspondence intensified amid efforts to sate the desire for 'hard news' concerning loved ones. The obligation of shielding selected family members burdened both combatant and non-combatant brothers. Many felt obliged to write what Kennard Bliss termed 'some sort of "cheer O!" stuff', whereas in reality, as he confided to his brother, 'I tremble at the knees "from morn to dewy eve". ${ }^{320}$ Siblings became co-conspirators in these acts of concealment, highlighting the need to look beyond the binary of recipient and sender, to explore the wider relational acts of duty and obligation threaded through these communications.

Brothers and sisters took care to protect shared confidences. In May 1917, Tom King informed his brother, Alf, that he had not heard from his girlfriend, Flossie, 'for ages'. If he failed to return, Alf should preserve his privacy by destroying Flossie's letters to him. ${ }^{321}$ The Falk brothers kept secrets from their parents, one letter hinting at franker communications unsuitable for wider dissemination. Losing track of Geoff's school holidays, Cecil had sent one 'unreadable' letter. Apologising for his thoughtlessness, Cecil promised to 'bear in mind your point i.e. careful letters in holidays \& say what I like in term'. ${ }^{322}$ Nurse Kate Luard expected her letters to be circulated among her ten surviving adult siblings, elderly widowed father, neighbourhood friends and wider family. Her sisters Daisy and Nettie spent hours happily reading, copying and sending out her letters and cards. Hence, Luard carefully earmarked those intended for the 'inner circle' of her most trusted sisters. ${ }^{323}$ Even within this tight-knit grouping, there was a layering of confidences. One letter, in which Kate spoke of an RAMC major, 'the love of her life', was preserved for the eyes of her sister Georgina only. ${ }^{324}$ Such markings demonstrate a level of familial trust; Luard's 
distant requests for privacy were respected within the family household.

Where direct correspondence between brothers proved difficult, siblings demonstrated the closeness of their brotherly ties by frequent references to brothers in family letters. For those conscientious objectors sentenced to imprisonment with hard labour for refusing to submit to army regulations, letters home were heavily censored and restricted to one per month. ${ }^{325}$ Despite this, and the length restrictions imposed by the regulation format, men endeavoured to express fraternal concern. Percy Wall, writing from Wormwood Scrubs, posed a number of questions that he was 'longing' to ask, all relating to his younger brother Dick, serving as a sergeant in the 8th Battalion King's Shropshire Light Infantry. 326 Percy's hunger for news was more than polite convention. The Wall brothers adopted differing attitudes to military service. Percy's objection to the war was in line with the pacifist views of his parents. Dick determined to follow the example of his peers when the time came for him to be conscripted. Regardless of this fundamental divergence in attitudes towards the war, Percy continued to demonstrate his ongoing concern for his sibling. The few surviving letters from Dick to Percy show how brotherly ties transcended barriers of language and divergent political views. Recovering in a rest camp after a 'pretty bad' fever, Dick signed off 'your ever affectionate brother', with ten kisses scrawled at the bottom of the page. ${ }^{327}$ Even in these most trying of circumstances, brothers strove to demonstrate affection for each other.

\section{Memoirs and memorials}

Sibling memoirs and written memorials assume many forms: memorial books; published and unpublished memoirs; dedicated sections in autobiographical and semi-autobiographical works; and poetry. War memoirs often present the war as a discontinuity in the author's life - a trait compounded by the temporal framing of the war years and consequent omission of early family or postwar life. This device enabled veterans to ring-fence an episode over which they had little or no control. Another distancing tendency 
led some siblings to turn to autobiographical fiction rather than a factual narrative. ${ }^{328}$ Not all memoirs can be categorised as reflective works. Many appeared during the war or shortly after its end, falling outside of the 'old self looking back' model. ${ }^{329}$ Fraternal memoirs form a significant sub-genre of these works, the lives under reflection being grounded in childhood and youth. ${ }^{330}$ Intrinsic to the writing of such works was the knowledge that the 'first volume' of their brothers' lives would never have a second or third. ${ }^{331}$

Jens Brockmeier adopts the term 'thick description' to explain the 'mishmash of experiences - past, present, possible, and anticipated' that must be navigated during the autobiographical process. ${ }^{332}$ This process of remembering - the ordering of images, stories and emotions, and their placement within narratives - is shaped and extended by a network of meanings including the familial, the cultural, the economic, the social and the historical. ${ }^{333}$ The memoirs considered here were all written in the twentieth century, which, as Meyer observes, represents a relatively short time-span within which to consider shifts in masculinity. Retrospective accounts enabled men to draw on the 'common threads of cultural understanding' of both warfare and masculinity to define both their brothers' and their own identities as soldiers, as brothers and as men. ${ }^{334}$ Alongside the valorisation of the soldier and the masculine norms of dutiful sons and breadwinning husbands, fraternal narratives allow us to add a further masculine discourse built around the loved and loving.

The reflective quality of life-writing, argues Strange, enabled adult children to impose affective frameworks on mundane features of their past, renegotiating the dynamics of relationships. ${ }^{335}$ Sibling memoirs reinterpret childhood practices when framing bonds with brothers and sisters. Within these fragmented discourses of grief, we see snapshots of a short-lived life, enlivened by particular episodes plucked from everyday life. Wartime deaths located the life of one of the sibling unit within the temporal boundary of the Great War and the preceding years. The element of traumatic remembering occasioned by wartime deaths complicated this task as siblings passed life milestones and anniversaries overshadowed by the absence of a loved one. Anger, guilt and grief influenced their choices when recording their own and their siblings' life stories. As discussed in Chapter 7, clues can be found in the structure of memoirs, in 
dedications and footnotes and in the naming of chapters. Some memoirs follow the chronology of a life, some the chronology of the war, and in some the two merge, with a wartime death ending the life being told. ${ }^{336}$

The inclusion of the trivial forces the reader into the role of eavesdropper on matters 'too personal to witness'. ${ }^{337}$ Yet sibling memorial-keeping inevitably inhabits this terrain, vesting trivial matters with greater emotional intensity as fragments of a brief life are desperately captured before they fade into the recesses of memory. The routine nature of sibling practice vested the traits and behaviours that stood out with especial meaning. Staking their claims to intimate knowledge of their subjects, siblings' interpretive labour was an active form of memory keeping. Their interlocutory' role was similar to that of the soldier-poets, inhabiting the no man's land between the combatant dead and the mourning communities of the living. ${ }^{338}$ The absence of close friends able to flesh out details of men's personalities and daily lives increased the difficulty of capturing memories for surviving siblings. This dilemma influenced Virginia Woolf's generational critique of Edward Marsh's 1918 memoir of Rupert Brooke. With so many of Brooke's contemporaries killed in combat, the picture produced by the older Marsh was 'inevitably incomplete'. ${ }^{339}$

Memorial books or 'memoirs to the dead' were ubiquitous during the war years. ${ }^{340}$ This was not, as Victoria Stewart believes, a form of 'controlled forgetting'. The amateur status of authors, combined with the semi-public nature of these works, often privately published and circulated within an intimate circle of family and friends, has consigned them to a genre of minor interest. Bette London advocates their significance as sources for understanding both the culture of remembrance and the emotional lives of individuals. ${ }^{341}$ People often turn intuitively to writing as a way of confronting and surviving trauma. ${ }^{342}$ Wartime experiences stirred the Welsh author and nationalist Kate Roberts to write. 'Death,' she explained, 'pulls the scales off one's eyes. ${ }^{343}$ Roberts's trajectory fits into Sharon Ouditt's argument that the war created an enabling space for women 'to work, think and practise as artists'. ${ }^{344}$ London's suggestion that memorial books provided women with a means of entering the public war discourse is more 
problematic, given the visible presence of women in commemorations. There is a stronger case to be made that grieving men were excluded from this discourse. Untold or borderline stories are better understood by a focus on how and why personal stories are recalled and told. ${ }^{345}$ Ouditt's 'othering' of the VADs or munionettes could equally be the 'other' of the male non-combatant or the grieving soldier-brother.

There were two spikes in the publication of memoirs written by former combatants. The first raft of 'disillusionment memoirs' appeared in the years 1928-31. In the 1960s, when approximately two million veterans were still alive, fiftieth-anniversary commemorations generated renewed interest in the Great War, spurring a further boom of publications and initiatives to preserve the voices of surviving veterans. ${ }^{346}$ As a consequence, the memories of a broad range of wartime experiences have appeared in publication. ${ }^{347}$ The perception that memoirs are unrepresentative, biased towards the 'exceptional' or the elite, is challenged by the democratisation of memoir publishing. An undiminished fascination with the war, combined with a burgeoning appetite for family history and the lived experience of war, led to men and women of all classes (and their families) regarding their war experience as exceptional and worth recording. ${ }^{348}$ This time-frame encompasses two 'memory booms'. The first followed the Armistice and was symbolised by a wave of war memorials and services. ${ }^{349}$ The Imperial War Museum records over 80,000 memorials in the United Kingdom, Channel Islands and the Isle of Man, transforming urban landscapes into a 'testimonial tract' and imposing a 'culture of remembrance' on urban and rural populations. ${ }^{350}$ The second 'boom' originated in the 1990s with the cultural and intellectual investigation of trauma in communities and individuals affected by the Second World War and later conflicts. ${ }^{351}$ From the Great War's fiftieth anniversary in the 1960s onwards, each decade of the twentieth century marked the anniversary of battles of national significance, the war's commencement and the Armistice. Accompanying this was renewed public reverence for the surviving veterans and acknowledgement that their numbers were dwindling each year, culminating in the death of Harry Patch, known as 'The Last Fighting Tommy', on 25 July 2009. ${ }^{352}$ 
Winter emphasises the importance of the demographic for the transmission of memories; the 1960s and 1970s also marked the age when many surviving veterans and their younger siblings became grandparents. This link between the old and their young grandchildren 'is so central to the concept of memory that its significance may have simply passed us by' and contributed to family war stories and myths becoming embedded in the collective memory by their inclusion in histories, fiction, exhibitions and museums. ${ }^{353}$ It is useful to widen our definition of 'generations' to include nephews and nieces, a category of family relationships frequently overlooked, yet carrying fraternal responsibilities for surviving brothers. My Dear Ralph (1994), the edited collection of the wartime letters of the Baines family, was initially undertaken by the daughter of Keenie Baines, who inherited Ralph's exercise books. Together with the surviving Baines siblings and her cousins, Diana Swarbrick re-edited Ralph's original 'painstaking' act of familial curation. After Diana's death, her brother saw the project through to completion. ${ }^{354}$

Fred Lloyd, the youngest in a family of sixteen, joined the army with his brothers Tom and Bill. Reflecting on their 'terrible' wartime deaths, it was his brother Bill, just one year older, whom he missed the most. 'We grew up together. We played together and went to school together. Everything we did, we did together.' ${ }^{355}$ Grief for his lost sibling and their anticipated future growing old together replaced his childhood companion. Such fraternal stories and acts of memory keeping are embedded in letters, diaries, memoirs, interviews and fictionalised accounts. Vital signifiers of sibling 'love', they illustrate the range of support, comfort and protection provided to combatants by their brothers and sisters.

\section{Notes}

1 Memoir, William Percy Campbell, IWM 73/37/1.

2 The privileging of the emotional bonds between soldiers in the literature has sidelined men's significant bonds with the home front. See, A. Gregory, The Last Great War. British Society and the First World War (Cambridge, 2008), p. 134. 
3 V. H. Bedford, 'Sibling Research in Historical Perspective: The Discovery of a Forgotten Relationship', American Behavioral Scientist, 33:1 (1989), pp. 6-18; L. Davidoff, Thicker than Water. Siblings and Their Relations 1780-1920 (Oxford, 2012), p. 1; A. Harris, Siblinghood and Social Relations in Georgian England. Share and Share Alike (Manchester, 2012), p. 56; D. P. Irish, 'Sibling Interaction: A Neglected Area of Family Life Research', Social Forces, 42:3 (1964), pp. 279-288; R. Sanders, Sibling Relationships: Theory and Issues for Practice (Basingstoke, 2004), p. 1.

4 V. Sanders, The Brother-Sister Culture in Nineteenth-Century Literature (London, 2002); J. Watson, Fighting Different Wars. Experience, Memory, and the First World War in Britain (Cambridge, 2004); A. Woollacott, 'Sisters and Brothers in Arms: Family, Class, and Gendering in World War I Britain', in M. Cooke and A. Woollacott (eds), Gendering War Talk (Princeton, 1993).

5 M. Roper, The Secret Battle. Emotional Survival in the Great War (Manchester, 2009), p. 6.

6 Davidoff, Thicker than Water, pp. 79-85.

7 M. Anderson, 'The Social Implications of Demographic Change', in F. M. L. Thompson (ed.), The Cambridge Social History of Britain, 1750-1950 (Cambridge, 1990), p. 39.

8 P. Cox, Demography (Cambridge, 1976), p. 355; P. Dewey, War and Progress. Britain 1914-1945 (London, 1997), pp. 52-53.

9 Davidoff, Thicker than Water, pp. 336-337.

10 As late as 1950, older people (aged eighty and over) had around eight ever-born siblings on average. The larger figures for average siblingship size compared to average family size can be explained by a number of reasons: a distortion caused by the relatively high proportion of childless households; calculations weighted towards larger families; and the fact that the number of living siblings was much smaller than the number of ever-born siblings. M. Murphy, 'Changes in Family and Kinship Networks Consequent on the Demographic Transitions in England and Wales', Continuity and Change, 25:1 (2010), pp. 125-126; Ibid., 'Long-Term Effects of the Demographic Transition on Family and Kinship Networks in Britain', Population and Development Review, 37:Supp (2011), p. 67.

11 N. Mitchison, All Change Here. Girlhood and Marriage (London, 1975); Ibid., You May Well Ask. A Memoir 1920-1940 (London, 1986, 1979); D. Scarisbrick (ed.), My Dear Ralph. Letters of a Family at War, 1914-1918 (London, 1994).

12 Harris, Siblinghood and Social Relations in Georgian England, p. 5. 
13 Davidoff, Thicker than Water; A. Atkins, We Grew Up Together. Brothers and Sisters in Nineteenth-Century America (Chicago, 2001); Harris, Siblinghood and Social Relations in Georgian England; C. D. Hemphill, Siblings. Brothers and Sisters in American History (Oxford, 2011).

14 A. Harrison, Three Brothers (London, 1919), p. 70.

15 T. K. Hareven, 'The History of the Family and the Complexity of Social Change', American Historical Review, 96:1 (1991), pp. 95-124.

16 Three studies have focused on the role of siblings as agents of intergeneration change: Atkins, We Grew Up Together; Harris, Siblinghood and Social Relations in Georgian England; Hemphill, Siblings.

17 Ibid., pp. 8, 108-109.

18 Ibid., p. 4.

19 Pierre Bourdieu believes that the incorporation of a watershed traumatic event into everyday practice marks a particular generation as a significant social force. K. Mannheim, 'The Problem of Generations', Psychoanalytic Review, 57:3 (1963), p. 7; P. Bourdieu, “Youth” Is Just a Word', in P. Bourdieu (ed.), Sociology in Question (London, 1980, 1993), pp. 94-102.

20 J. Edmunds and B. S. Turner, Generations, Culture and Society (Buckingham, 2002), p. 10.

21 D. Cannadine, 'War and Death, Grief and Mourning in Modern Britain', in J. Whaley (ed.), Mirrors of Mortality (London, 1981), pp. 199-201; J. Winter, 'Britain's "Lost Generation" of the First World War', Population Studies, 31:3 (1977), p. 465.

22 L. Ugolini, Civvies. Middle-Class Men on the English Home Front, 1914-18 (Manchester, 2013), pp. 4-5.

23 M. W. Cannan, Grey Ghosts and Voices (Kineton, 1976), p. 75. The VAD, run under the auspices of the Red Cross or the Order of St John of Jerusalem, was established in 1909 to provide volunteer support to the wounded in time of war.

24 Letter, 23 May 1916, A. E. Bendall, IWM 01/36/1.

25 J. Calder, The Nine Lives of Naomi Mitchison (London, 1997), p. 52.

26 A clear demarcation of the time of life when individuals might expect these stages to occur settled into a set pattern only in the 1960s and 1970s. M. Anderson, 'The Emergence of the Modern Life Cycle in Britain', Social History, 10:1 (1985), pp. 85-86; T. K. Hareven, 'Family Time and Historical Time', Daedalus, 106 (1977), pp. 60-62.

27 Letter, 20 February 1915, E. Heaton, IWM 03/29/1. 
28 On 29 November 1915 the list of reserved occupations was extended to include 'bleaching, dyeing, calico printing and textile finishing trades'. The Times, 20 December 1915.

29 Postcard, n.d., 1915, F. Hammerton, IWM 08/95/1.

30 Friends Roland Leighton, Edmund Brittain and Victor Richardson were branded the 'Three Musketeers' by Roland's mother; the offspring of the aristocratic friendship group 'the Souls' called themselves 'The Corrupt Coterie'. V. Brittain, Testament of Youth. An Autobiographical Story of the Years 1900-1925 (London, 1933, 1978), p. 231; A. Powell, Bim. A Tribute to the Honourable Edward Wyndhamtennant, Lieutenant, 4th Battalion Grenadier Guards 1897-1916 (Salisbury, 1990), p. 20; A. Lambert, Unquiet Souls: The Indian Summer of the British Aristocracy, 1880-1918 (London, 1984).

31 Brittain, Testament of Youth, p. 445.

32 The emphasis in this, and all other direct quotes throughout, is as in the original, unless otherwise stated. Letter, 26 June 1917, M. F. Foxell, IWM 11936.

33 Letter, 15 October 1916, F. Cocker, IWM 82/11/1.

34 Brittain, Testament of Youth, p. 495.

35 S. Ouditt, Fighting Forces, Writing Women. Identity and Ideology in the First World War (London, 1994), pp. 120-121; R. Holland, The Lost Generation (London, 1932); M. W. Cannan, The Lonely Generation (London, 1934).

36 T. Clewell, 'Consolation Refused: Virginia Woolf, the Great War, and Modernist Mourning', MFS Modern Fiction Studies, 50 (2004), pp. 198-199.

37 Approximately 70 per cent of men in the British army were under thirty years old and 40 per cent were under twenty-four. Additionally, Richard van Emden has drawn attention to the significant number of underage volunteers. Roper, The Secret Battle, p. 5; J. Winter, The Great War and the British People (Basingstoke, 1985), pp. 82-83; R. van Emden, Boy Soldiers of the Great War (London, 2005), pp. 367-374.

38 S. Grayzel and T. Proctor (eds), Gender and the Great War (Oxford, 2017), p. 5.

39 Diary entries 7 August 1914 and 2 September 1914, V. Brittain, Chronicle of Youth. Great War Diary, 1913-1917, ed. A. Bishop (London, 2002), pp. 89-90, 101.

40 Letter, n.d., T. Povey, IWM 08/147/1.

41 Letters, 4 January 1917 and 8 February 1917, in Scarisbrick, My Dear Ralph, pp. 75, 83. 
42 Letters, 16 June 1917, 27 August 1917, in Ibid., pp. 110, 122-123.

43 Letter, 9 January 1916, in Ibid., p. 26.

44 Anthropologists have observed how initiation rites promoted traits of 'intense comradeship and egalitarianism' among neophytes. V. Turner, The Ritual Process. Structure and Anti-Structure (New York, 1969), p. 95.

45 U. Frevert, A Nation in Barracks. Conscription, Military Service and Civil Society in Modern Germany (Oxford, 2004); L. Davidoff, 'The Family in Britain', in F. M. L. Thompson (ed.), The Cambridge Social History of Britain 1750-1950 (Cambridge, 1990), pp. 71-130.

46 Childers to Sir Frederick Roberts, cited by D. French, Military Identities. The Regimental System, the British Army, and the British People c.1870-2000 (Oxford, 2005), pp. 76-78.

47 A. Tattersall, IWM 07/40/1.

48 Lord Derby, a former mayor of Liverpool, was eager for the city to be among the first to raise one of the new volunteer battalions. Appealing for men to come forward, he coined the phrase a 'battalion of Pals', firmly cementing the association between service and comradeship within the public discourse. P. Simkins, Kitchener's Army. The Raising of the New Armies 1914-1916 (Manchester, 1988), pp. 82-84, 100; Liverpool Echo, 27 August 1914, 29 August 1914.

49 Simkins, Kitchener's Army, pp. 138-146.

50 Preston Herald, 9 September 1914.

51 Paragraph 333(iv) of the King's Regulations contained a provision enabling young brothers to ask permission to be transferred subject to the agreement of both siblings. If permission was initially refused, an appeal could be made to the General Officer Commanding in Chief, who had authority to transfer either the elder or younger brother to the other's unit. War Office, The King's Regulations and Orders for the Army. 1912; Reprinted with Amendments Published in Army Orders up to 1st August, 1914 (London, 1916), p. 60.

52 Family Life and Work Experience survey (FLWE) 2000/098. Paul Thompson and Trevor Lummis' FLWE, a qualitative survey of Edwardian family and working life in England, Wales and Scotland, was conducted in the 1970s on a cross-national sample of 222 men and 231 women born between 1870 and 1908. The study asked specific questions about the number and ages of siblings, siblingrelated chores and shared spaces, how parents expected siblings to behave towards each other, and whether a close relationship was enjoyed with one sibling in particular. Respondent details have been anonymised throughout. 
53 Interview, R. Hill, IWM 10770.

54 Section 2(1) made provision for men to claim exemptions on the following grounds: engagement in work of national interest; serious hardship due to exceptional financial, domestic or business obligations; ill health or infirmity; and conscience. Military Service Act 1916.

55 W. Ellsworth-Jones, We Will Not Fight: The Untold Story of the First World War's Conscientious Objectors (London, 2008), pp. 103, 180.

56 For a discussion of public attitudes to conscientious objectors, see: L. Bibbings, Telling Tales about Men. Conceptions of Conscientious Objectors to Military Service During the First World War (Manchester, 2009), pp. 89, 98-111; N. F. Gullace, 'The Blood of Our Sons'. Men, Women, and the Renegotiation of British Citizenship During the Great War (London, 2002), pp. 181-183.

57 M. Jones, The Last Great Quest. Captain Scott's Antarctic Sacrifice (Oxford, 2003), pp. 146-149.

58 The 'vast crowds' attending the national memorial service at St Pauls on 15 February 1913 mirrored those at services held throughout the country, matching those following the Titanic disaster on 14 April 1912: Manchester Guardian, 15 February 1913; Jones, The Last Great Quest, pp. 6, 103.

59 The appeal of Scott's story was still flourishing in the years immediately after the Second World War: M. Francis, 'A Flight from Commitment? Domesticity, Adventure and the Masculine Imaginary in Britain after the Second World War', Gender \& History, 19:1 (2007), pp. 163-185.

60 K. Barclay, 'Review Article: The History of the Family: Structures, Power and Emotion', Women's History Network Magazine, 72 (2013), pp. 33-34; B. Caine (ed.), Friendship: A History (London, 2009), p. 223; Davidoff, Thicker than Water, pp. 37-38.

61 Tied into these within working-class culture was the concept of 'sharing': J. Bourne, 'The British Working Man in Arms', in H. Cecil and P. Liddle (eds), Facing Armageddon (London, 1996), p. 346; R. Williams, Keywords. A Vocabulary of Culture and Society (London, 1973), p. 133.

62 Davidoff, Thicker than Water, p. 38.

63 S. Cole, Modernism, Male Friendship and the First World War (Cambridge, 2003), pp. 77, 31-33.

64 S. H. Newbolt, Clifton Chapel, and Other School Poems (London, 1908), pp. 5-7; J. Stallworthy (ed.), The New Oxford Book of War Poetry (Oxford, 2014), pp. xxvi-xxvii. 
65 P. Donaldson, Remembering the South African War. Britain and the Memory of the Anglo-Boer War, from 1899 to the Present (Liverpool, 2013), pp. 96-97.

66 Accepted in British and Australian scholarship, Winter and Prost observe a different experience among Russian, German and Italian troops. D. Winter, Death's Men. Soldiers of the Great War (London, 1978), p. 45; B. Gammage, The Broken Years. Australian Soldiers in the Great War (Canberra, 1974), pp. 101-103; J. Winter and A. Prost, The Great War in History. Debates and Controversies, 1914 to the Present (Newcastle-upon-Tyne, 2014), pp. 94-96.

67 I. R. Bet-El, Conscripts. Forgotten Men of the Great War (Stroud, 1999), pp. 42-43; Cole, Modernism, p. 138; J. S. Goldstein, War and Gender. How Gender Shapes the War System and Vice Versa (Cambridge, 2001), pp. 195-196.

68 E. Madigan, Faith under Fire. Anglican Army Chaplains and the Great War (London, 2011); Michael Snape presents a counterargument to this perspective: M. Snape, God and the British Soldier. Religion and the British Army in the First and Second World Wars (Abingdon, 2005).

69 A. Marrin, The Last Crusade. The Church of England in the First World War (Durham, NC, 1974), pp. 184-186.

70 For examples see: A. H. Gibbs, The Grey Wave (London, 1920), p. 580; G. Malins, How I Filmed the War. A Record of the Extraordinary Experiences of the Man Who Filmed the Great Somme Battles Etc (London, 1920), pp. 95, 96, 102; G. Knight, 'Brother Bosch'. An Airman's Escape from Germany (London, 1919).

71 The gold fringe framing the branch standards represents 'brotherhood'. The standard was designed by Colonel E. C. Heath in 1922. G. Wootton, The Official History of the British Legion (London, 1956), p. 63.

72 Barbara Caine provides an overview of the use of brotherhood as a troop in the socialist movement. H. Caine, Our Girls: Their Work for the War (London, 1916), p. 255; T. C. Kennedy, The Hound of Conscience. A History of the No-Conscription Fellowship (Arkansas, 1981), pp. 44, 231.

73 Caine, Our Girls.

74 J. Lee, 'Sisterhood at the Front: Friendship, Comradeship, and the Feminine Appropriation of Military Heroism among World War I First Aid Nursing Yeomanry (FANY)', Women's Studies International Forum, 31 (2008), p. 24; D. Condell and J. Liddiard, Working for Victory? Images of Women in the First World War, 1914-1918 (London, 1987), p. 49. 
75 Davidoff, Thicker than Water, p. 35.

76 Hemphill, Siblings, p. 6.

77 S. Das, Touch and Intimacy in First World War Literature (Cambridge, 2005), p. 111.

78 Caine, Our Girls, p. 218.

79 FLWE 2000/396.

80 S. Humphries, 'The Last Survivors of the First World War', $B B C$ History (2018). An account is also provided in H. Patch and R. van Emden, The Last Fighting Tommy. The Life of Harry Patch, the Oldest Surviving Veteran of the Trenches (London, 2007), p. 111.

81 Ibid., pp. 196-197; J. Bourke, Dismembering the Male. Men's Bodies, Britain and the Great War (London, 1996), pp. 153-156.

82 Mitchison, All Change Here, p. 106.

83 The respondent was the middle sibling of five, with two older brothers and a younger brother and sister. FLWE 2000/265.

84 Interview, J. Maxwell-Wedderburn, IWM 9146.

85 L. Davidoff, 'Kinship as a Categorical Concept: A Case Study of Nineteenth-Century English Siblings', Journal of Social History, 39:2 (2005), p. 414.

86 Hareven, 'Family Time and Historical Time', p. 62.

87 Anderson, 'The Social Implications of Demographic Change', pp. 29-32.

88 C. Graves, The Bad Old Days (London, 1951), p. 12.

89 FLWE 2000/302.

90 FLWE 2000/077.

91 FLWE 2000/427.

92 See, for example: V. G. Cicirelli, 'Sibling Influence Throughout the Lifespan', in M. E. Lamb and B. Sutton-Smith (eds), Sibling Relationships (Hillsdale, NJ, 1982), pp. 267-284; L. S. Young and S. Frosh, "And Where Were Your Brothers in All This?" A Psychosocial Approach to Texts on "Brothering"', Qualitative Research, 10 (2010), pp. 511-531; B. Sutton-Smith, 'Birth Order and Sibling Status Effects', in M. E. Lamb and B. Sutton-Smith (eds), Sibling Relationships (Hillsdale, NJ, 1982), p. 161.

93 R. W. Connell, Masculinities (London, 1995), p. 122.

94 FLWE 2000/031.

95 FLWE 2000/309.

96 FLWE 2000/134.

97 Laura King's thoughtful analysis of parenting influences does not consider the role played by siblings exercising 'parental' duties. L. King, 
Family Men. Fatherhood and Masculinity in Britain, 1914-1960 (Oxford, 2015).

98 Harris, Siblinghood and Social Relations in Georgian England, p. 38.

99 Harrison, Three Brothers, p. 41.

100 D. Kempson, 'Memory Keepers: A Narrative Study of Siblings Never Known', Death Studies, 34:8 (2010), p. 739.

101 Murphy, 'Changes in Family and Kinship Networks', p. 125.

102 Those born in 1921 attained the age of forty-one before their father died, whereas those born in 1946 would be 56 before both parents died. Anderson, 'The Emergence of the Modern Life Cycle in Britain', p. 76.

103 Ella Lethem, Liddle WW1/DF/074; G. Wells, Cadbury MS 117.

104 Diary, 2 July 1916, Foxell, IWM 11936.

105 Diary, 31 May 1917, Lethem, Liddle WW1/DF/074.

106 Leeds Mercury, 16 June 1916.

107 P. Hamilton, Three Years or the Duration. The Memoirs of a Munition Worker, 1914-1918 (London, 1978), pp. 109-111.

108 C. Booth, Life and Labour of the People in London (London, 1902-1903); B. S. Rowntree, Poverty. A Study of Town Life (London, 1902); cited by, J. Harris, Private Lives, Public Spirit. A Social History of Britain, 1870-1914 (Oxford, 1993), p. 65.

109 M. Young and P. Willmott, Family and Kinship in East London (London, 1957), p. 77; C. Rosser and C. Harris, The Family and Social Change. A Study of Family and Kinship in a South Wales Town (London, 1965, 1983), pp. 164-165; A follow-up study to Rosser and Harris found that sibling proximity and contact had declined in the latter half of the twentieth century: N. Charles et al., 'The Family and Social Change Revisited', in R. Edwards (ed.), Researching Families and Communities. Social and Generational Change (London, 2008), p. 124; P. Townsend, The Family Life of Old People: An Inquiry in East London (London, 1957), pp. 104-105.

110 Harrison, Three Brothers, p. 77.

111 Scarcity of leave was a common complaint. In June/July 2017, over 107,000 British soldiers had had no leave for 18 months, and 403,000 no leave for 12 months. J. G. Fuller, Troop Morale and Popular Culture in the British and Dominion Armies, 1914-1918 (Oxford, 1990), p. 72.

112 Diary, 6 April 1918, Wells, Cadbury MS 117.

113 King, Family Men; C. Langhamer, The English in Love. The Intimate Story of an Emotional Revolution (Oxford, 2013).

114 M. Rustin, 'Taking Account of Siblings - a View from Child Psychotherapy', Journal of Child Psychotherapy, 33:1 (2007), pp. 23, 34. 
115 J-M. Strange, Fatherhood and the British Working Class, 1865-1914 (Cambridge, 2015), 15-16.

116 OED Online, date accessed: 5 December 2017.

117 For observations about the intensity of sister-brother wartime bonds in writings by female authors, see: K. Kennedy, “A Tribute to My Brother": Women's Literature and Its Post-War Ghosts', Journal of War \& Culture Studies, 8:1 (2015), pp. 7-23; Woollacott, 'Sisters and Brothers in Arms'; Sanders, The Brother-Sister Culture.

118 Woollacott, 'Sisters and Brothers in Arms', p. 131.

119 L. Davidoff and C. Hall, Family Fortunes. Men and Women of the English Middle Class 1780-1850 (London, 1987), p. 350; Sanders, The Brother-Sister Culture, pp. 11-12.

120 Calder, The Nine Lives of Naomi Mitchison, p. 15.

121 Vera Brittain compared the hills around Buxton to the walls of a prison. Brittain, Testament of Youth, p. 56; Mitchison, All Change Here, pp. 42-49, 69.

122 For details of the FLWE see note 52.

123 FLWE 2000/105.

124 FLWE 2000/038.

125 FLWE 2000/030.

126 FLWE 2000/078.

127 FLWE 2000/283.

128 FLWE 2000/187.

129 An analysis undertaken by the author of over 460 interviews found that 66 per cent of respondents stated that they had a positive relationship with all their siblings, with only 5 per cent specifying a negative sibling bond. Some caution is necessary. As Irwin and Winterton observe, the secondary analysis of existing data sets requires the consideration of the wider context, including which questions were asked and how they were asked. S. Irwin and M. Winterton, Qualitative Secondary Analysis. A Guide to Practice (Leeds, 2012), p. 15; Ibid., Debates in Qualitative Secondary Analysis. Critical Reflections (Leeds, 2011), pp. 9-10.

130 H. Kelley, Close Relationships (New York, 1983), p. 38.

131 FLWE 2000/025.

132 S. Ahmed, The Promise of Happiness (Durham, NC, 2010), pp. 45-46.

133 E. Griffin, 'The Emotions of Motherhood: Love, Culture and Poverty in Victorian England', American Historical Review, 123 (2018), p. 74.

134 Diary, 12 December 1918, M. Gilbert, Plough My Own Furrow: The Story of Lord Allen of Huntwood as Told through His Writings and Correspondence (London, 1965), p. 127. 
135 Bet-El, Conscripts, pp. 131, 143; Bourke, Dismembering the Male, p. 21; J. Meyer, Men of War. Masculinity and the First World War in Britain (Basingstoke, 2009), p. 15; Roper, The Secret Battle, p. 6; Ibid., 'Nostalgia as an Emotional Experience in the Great War', The Historical Journal, 54:2 (2011), pp. 421-451.

136 Roper's analysis of 5,000 letters found that almost half (47.5 per cent) were addressed to the mother. Joy Damousi and Jenny Hartley observed a similar weighting. Roper, The Secret Battle, pp. 59-60; J. Damousi, The Labour of Loss. Mourning, Memory, and Wartime Bereavement in Australia (Cambridge, 1999), p. 61; J. Hartley, " "Letters Are Everything These Days": Mothers and Letters in the Second World War', in R. Earle (ed.), Epistolary Selves (Abingdon, 1999), pp. 183-195.

137 Bourke, Dismembering the Male; Meyer Men of War; Roper, The Secret Battle.

138 Letters, 21 January 1917, 31 May 1917, 2 June 1917, 4 June 1917, in Scarisbrick, My Dear Ralph, pp. 77-79, 98-99.

139 This phrase is adapted from Roper's concept of 'mothering at a distance', Roper, The Secret Battle, p. 51.

140 Davidoff, Thicker than Water, p. 116; J. Finch, Familial Obligations and Social Change (London, 1989), pp. 13-56; J. Fink, 'Care. Meanings, Identity and Morality', in J. Finch (ed.), Care (London, 2004), p. 117.

141 H. Graham, 'Caring: A Labour of Love', in J. Finch and D. Groves (eds), A Labour of Love: Women, Work and Caring (London, 1983), pp. 16-17.

142 J. Finch, 'Kinship as "Family" in Contemporary Britain', in F. Ebtehaj et al. (eds), Kinship Matters (Oxford, 2006), pp. 293-306; J. Mitchell and J. Goody, 'Family or Familiarity?', in A. Bainham et al. (eds), What Is a Parent? (Oxford, 1999), p. 113; D. Morgan, Family Connections. An Introduction to Family Studies (London, 1996); Ibid., Rethinking Family Practices (Basingstoke, 2011); Monique Scheer also adopts a 'practice'-based approach in her discussion of how to historicise emotions. M. Scheer, 'Are Emotions a Kind of Practice (and Is That What Makes Them Have a History)? A Bourdieuian Approach to Understanding Emotion', History and Theory, 51 (2012), pp. 199-200.

143 Ahmed, The Promise of Happiness, p. 47.

144 Davidoff, Thicker than Water, p. 110; P. Thompson and T. Lummis, Family Life and Work Experience before 1918 (Colchester, 2009).

145 Davidoff, Thicker than Water, p. 44. 
146 D. Morgan, 'Locating "Family Practices"', Sociological Research Online, 16:4 (2011), p. 14; Carol Smart's complementary conceptualisation of 'personal life' overcomes the distinction between public and private spheres, which has traditionally regarded family life as separate from other social spaces. C. Smart, Personal Life. New Directions in Sociological Thinking (London, 2007), pp. 28-30.

147 H. Ross and J. Milgrim, 'Important Variables in Adult Sibling Relationships: A Qualitative Study', in M. E. Lamb and B. SuttonSmith (eds), Sibling Relationships (Hillsdale, NJ, 1982), pp. 225, 228.

148 Bourne, 'The British Working Man in Arms', pp. 336, 341. The working class is not a homogeneous category, with place, in particular providing a key differential. S. Todd, The People. The Rise and Fall of the Working Class, 1910-2010 (London, 2014), p. 12.

149 J-M. Strange, 'Fatherhood, Providing, and Attachment in Late Victorian and Edwardian Working-Class Families', Historical Journal, 55:4 (2012), pp. 18-20; D. Miller, A Theory of Shopping (London, 1998), pp. 73-110.

150 Cited by, H. Medick and D. W. Sabean, 'Interest and Emotion in Family and Kinship Studies: A Critique of Social History and Anthropology', in H. Medick and D. W. Sabean (eds), Interest and Emotion (Cambridge, 1984), p. 27.

151 Roper, The Secret Battle, pp. 164-165, 183.

152 Strange, Fatherhood and the British Working Class, pp. 1007-1027.

153 L. Davidoff et al., The Family Story. Blood, Contract and Intimacy, 1830-1960 (London, 1999), p. 5; Davidoff is referring to a subset of historical studies focusing on Victorian youth gangs: S. Humphries, Hooligans or Rebels? An Oral History of Working-Class Childhood and Youth 1889-1939 (Oxford, 1981); G. Pearson, Hooligan. A History of Respectable Fears (London, 1983); A. Davies, 'Youth Gangs, Masculinity and Violence in Late Victorian Manchester and Salford', Journal of Social History, 32:2 (1998), pp. 349-369; Ibid., 'Youth Gangs and Late Victorian Society', in B. Goldson (ed.), Youth in Crisis? 'Gangs', Territoriality and Violence (London, 2011), pp. 38-54.

154 E. G. Pollack, 'The Childhood We Have Lost: When Siblings Were Caregivers, 1900-1970', Journal of Social History, 36:1 (2002), pp. 31-63.

155 FLWE 2000/054.

156 Atkins, We Grew Up Together, p. 14.

157 FLWE 2000/396.

158 FLWE 2000/123. 
159 FLWE 2000/427.

160 FLWE 2000/447.

161 Watson, Fighting Different Wars, pp. 3-4, 92-93.

162 Letter, 15 October 1915, J. Miller, IWM 01/48/1.

163 This brought the treatment of brothers' widows in line with that of the widower of sisters. After almost 70 years of intense debate, the Deceased Wife's Sister's Marriage Act was enacted in 1907. The Deceased Brother's Widow's Marriage Act was eventually introduced in 1921.

164 For a detailed background to the Bill and the long-running debates see, K. Chase and M. Levenson, The Spectacle of Intimacy. A Public Life for the Victorian Family (Princeton, 2000), pp. 105-120; S. Wolfram, In-Laws and Outlaws. Kinship and Marriage in England (London, 1987), pp. 80-82.

165 HC Hansard, 8 November 1920, 134: 821-822.

166 HC Hansard, 23 March 1920, 127: 237-238.

167 A Correspondent, 'Sex Equality in Regard to One Aspect of the Marriage Law', Common Cause, 28 January (1921), pp. 6-7.

168 Winter estimated that a third of the men killed in the war left widows. J. Winter, Sites of Memory, Sites of Mourning. The Great War in European Cultural History (Cambridge, 1995), p. 45.

169 HC Hansard, 5 June 1919, 116: 2206.

170 A. E. Wrench, IWM 85/51/1.

171 Roper uses the term 'emotional experience' to describe what was conscious to men and what they were able to communicate. Roper, The Secret Battle, pp. 19-20.

172 C. Acton, Grief in Wartime. Private Pain, Public Discourse (Basingstoke, 2007), p. 111.

173 Letter, 15 May 1915, P. Puckle, Liddle WWI/WO/097.

174 Quote from the anonymous author of a pamphlet published on the day the Unknown Warrior was interred at Westminster Abbey, 11 November 1920. To My 'Unknown' Warrior (London, 1920), p. 7.

175 N. Taylor, IWM 90/28/1 207.

176 J. Plamper, 'The History of Emotions: An Interview with William Reddy, Barbara Rosenwein, and Peter Stearns', History and Theory, 49:2 (2010), p. 237.

177 M. Roper, 'The Unconscious Work of History', Cultural and Social History, 11:2 (2014), pp. 171, 174, 177.

178 W. Reddy, 'Review. The History of Emotions: An Introduction by Jan Plamper', The History of Emotions Blog (2015), date accessed: 
14 November 2015, emotionsblog.history.qmul.ac.uk/2015/07/rev iew-the-history-of-emotions-an-introduction-by-jan-plamper/.

179 D. Miller, Stuff (Cambridge, 2010), pp. 50-54.

180 Mitchison, All Change Here, pp. 24, 89.

181 M. Francis, 'Tears, Tantrums, and Bared Teeth: The Emotional Economy of Three Conservative Prime Ministers, 1951-1963', Journal of British Studies, 41:3 (2002), p. 357.

182 For a discussion of the use of the male 'breadwinning' role as a marker of masculine citizenship by political groupings see, A. Clark, The Struggle for the Breeches. Gender and the Making of the British Working Class (London, 1995), pp. 141-157.

183 J. Tosh, 'What Should Historians Do with Masculinity? Reflections on Nineteenth-Century Britain', History Workshop Journal, 38 (1994), p. 181; O. Anderson, 'The Growth of Christian Militarism in Mid-Victorian Britain', English Historical Review, 86:338 (1971), pp. 21-22; P. Cominos, 'Late-Victorian Sexual Respectability and the Social System', International Review of Social History, 8:1 (1963), pp. 27-30; H. Cook, 'From Controlling Emotion to Expressing Feelings in Mid-Twentieth-Century England', Journal of Social History, 47:3 (2014), p. 1; A. Fletcher, Growing up in England. The Experience of Childhood 1600-1914 (New Haven, 2008).

184 W. M. Eagar, Making Men. The History of Boys' Clubs and Related Movements in Great Britain (London, 1953); G. Rosenthal, The Character Factory. Baden-Powell and the Origins of the Boy Scout Movement (London, 1986); M. Freeman, 'Muscular Quakerism? The Society of Friends and Youth Organisations in Britain, C.1900-1950', English Historical Review, CXXV:514 (2010), pp. 642-669; J. Springhall, Sure and Stedfast. A History of the Boys' Brigade, 1883-1993 (London, 1983); Ibid., 'Building Character in the British Boy: The Attempt to Extend Christian Manliness to Working-Class Adolescents, 1880-1914', in J. A. Mangan and J. Walvin (eds), Manliness and Morality (Manchester, 1987), pp. 52-94.

185 Davies, 'Youth Gangs'; M. Tebbutt, Being Boys. Youth, Leisure and Identity in the Inter-War Years (Manchester, 2012), p. 238.

186 Strange challenges David Vincent's assertion that the working classes did not experience 'pure' grief. J-M. Strange, Death, Grief and Poverty in Britain, 1870-1914 (Cambridge, 2005), pp. 9-10; D. Vincent, Bread, Knowledge and Freedom. A Study of WorkingClass Autobiography (London, 1981), pp. 223-247.

187 FLWE 2000/109. 
188 S. Olsen, Juvenile Nation. Youth, Emotions and the Making of the Modern British Citizen, 1880-1914 (London, 2014), pp. 51, 72.

189 C. Nelson, Family Ties in Victorian England (Westport, CN, 2007), pp. 104-107.

190 According to the 1851 religious census, 40 per cent of the population attended at least one church service. However, local surveys found that a truer figure was just over 25 per cent of the population. Cited by, P. Thompson, The Edwardians. The Remaking of British Society (London, 1992), pp. 173-174.

191 Cited by, J. Springhall, 'The Boy Scouts, Class and Militarism in Relation to the British Youth Movements, 1908-1930', International Review of Social History, 16:2 (1971), p. 143.

192 Cited by, A. Freeman, Boy Life and Labour. The Manufacture of Inefficiency (London, 1914), p. 125.

193 John Wilkinson extrapolates this figure from a Mass Observation survey of 2,000 adults conducted in 1966 which showed that 34 per cent of males in this age group had belonged to the Boy Scouts and a further 14 per cent were members of the Boys' Brigade. See, P. Wilkinson, 'English Youth Movements, 1908-30', Journal of Contemporary History, 4:2 (1969), p. 3.

194 Ibid., J. Springhall, Youth, Empire and Society. British Youth Movements, 1883-1940 (Beckenham, 1977); Ibid., Sure and Stedfast; A. Warren, 'Popular Manliness: Baden-Powell, Scouting and the Development of Manly Character', in J. A. Mangan and J. Walvin (eds), Manliness and Morality (Manchester, 1987), pp. 199-219.

195 V. Bailey, 'Bibles and Dummy Rifles: The Boys' Brigade', History Today, 33 (1983), p. 9.

196 K. Vallgårda et al., 'Emotions and the Global Politics of Childhood', in S. Olsen (ed.), Childhood, Youth and Emotions in Modern History (London, 2015), pp. 12-34.

197 W. Reddy, The Navigation of Feeling. A Framework for the History of Emotions (Cambridge, 2001), p. 323. This has some resonance with the concept of emotional economies attributed to the eighteenthcentury philosopher Francis Hutcheson, who wrote in 1728 that such economy of passions contributed to individual happiness and the greater good of society. U. Frevert, Emotions in History - Lost and Found (Budapest, 2011), p. 153.

198 J. Hopton, 'The State and Military Masculinity', in P. R. Higate (ed.), Military Masculinities (Westport, CT, 2003), pp. 113-114.

199 The Times, 3 August 1914.

200 Brittain, Testament of Youth, p. 197. 
201 A search for the phrase 'cool leadership' returned 337 notices and the search 'coolness and courage' found 4,126 notices. The term 'courage' on its own returned 5,541 notices.

202 Connell, p. 77; G. Dawson, Soldier Heroes. British Adventure, Empire and the Imagining of Masculinities (London, 1994), p. 24.

203 F. Lockwood, West Yorkshire Archive Service (WYAS) KC329.

204 B. Rosenwein, Emotional Communities in the Early Middle Ages (Cornell, 2007), p. 23; Plamper, pp. 225-226.

205 Reddy concurs with this, accepting the existence of multiple regimes on a spectrum of rigidity and the resulting necessity for individuals to navigate their way through contradictory emotional norms. B. Rosenwein, 'Worrying about Emotions in History', American Historical Review, 107:3 (2002), p. 842; Plamper, 'The History of Emotions', pp. 256-257; Reddy, Navigation, pp. 124-126.

206 Vallgårda, Alexander and Olsen argue that in the context of war, revolution, imperial encounters and population movements, emotional mobility would be impossible if Rosenwein's formulation held true. Vallgårda et al., 'Emotions', pp. 21-23.

207 Ahmed, The Promise of Happiness, p. 48.

208 Vallgårda et al. propose 'emotional frontiers' as a concept for exploring the competing or contradictory influences on children. Vallgårda et al., 'Emotions', pp. 21-25.

209 Roper, The Secret Battle, pp. 32-33.

210 For a discussion of attitudes to malingerers, shirkers and slackers, Bibbings, Telling Tales about Men, pp. 89-110; Bourke, Dismembering the Male, pp. 76-92.

211 Letter, 31 July 1916, F. Day, Liddle WW1/EP/015.

212 Brittain, Testament of Youth, p. 247.

213 H. Smith, Masculinity, Class and Same-Sex Desire in Industrial England, 1895-1957 (London, 2015), pp. 105-106.

214 Reddy, Navigation, pp. 128-129.

215 Ibid., pp. 57, 60.

216 Goldstein, War and Gender, p. 267; G. Mosse, The Image of Man. The Creation of Modern Masculinity (Oxford, 1996), p. 109.

217 The influential Russian military psychiatrist, Mikhail Dragomirov (1830-1905), stated that practice and routine was the most effective antidote to fear. J. Plamper, 'Soldiers and Emotion in Early Twentieth-Century Russian Military Psychology', in J. Plamper and B. Lazier (eds), Fear across the Disciplines (Pittsburgh, 2012), pp. 86-87.

218 Cook, 'From Controlling Emotion to Expressing Feelings', p. 9. 
219 Private Harry Drinkwater referred to the 'cold courage' of men facing trench warfare on the Western Front in his diary. H. Drinkwater, Harry's War. The Great War Diary of Harry Drinkwater, ed. J. Cooksey (London, 2013), pp. 131, 334.

220 F. Buckley, Q.6.A and Other Places. Recollections of 1916, 1917, 1918 (London, 1920).

221 P. Cearns, The Love of a Brother. From Plaistow to Passchendaele (London, 1917, 2011), p. 26.

222 Harrison, Three Brothers, pp. 78-79.

223 Letter, 20 June 1917, in Scarisbrick, My Dear Ralph, p. 113.

224 Brittain, Testament of Youth, p. 256.

225 Martin Francis observes similar respect for emotional outbursts in his study of Second World War RAF personnel. M. Francis, The Flyer. British Culture and the Royal Air Force (Oxford, 2008), p. 82.

226 A. Vingerhoets, Why Only Humans Weep. Unravelling the Mysteries of Tears (Oxford, 2013), pp. 31-32.

227 T. Dixon, Weeping Britannia. Portrait of a Nation in Tears (Oxford, 2015), pp. 142-145.

228 Harrison, Three Brothers, pp. 97-98.

229 Dixon, Weeping Britannia, p. 209.

230 The phrase 'stiff upper lip' was originally an Americanism coined in 1871. Towards the end of the nineteenth century it acquired its central quality of displaying bravery and hiding one's true feelings. Ibid., pp. 202-203.

231 Meyer, Men of War, p. 166.

232 Gary Sheffield puts the losses at 744,702, slightly higher than Jay Winter's estimate of 722,785. G. Sheffield, Forgotten Victory. The First World War: Myths and Realities (London, 2001), p. 6; Winter, The Great War, p. 71.

233 Ibid., 'Britain's “Lost Generation”, pp. 449-466.

234 Cannadine, 'War and Death', Grief and Mourning, pp. 187-242.

235 Davidoff, Thicker than Water, pp. 330-332; Kennedy argues that the literate, middle-class sisters she examines experienced 'a very particular combination of guilt, anger, grief and self-questioning', Kennedy, " "A Tribute to My Brother", p. 8.

236 Letter to Nick Gammage, 15 March 1991, C. Reid (ed.), Letters of Ted Hughes (London, 2007), pp. 592-593.

237 The Times, 18 October 1975.

238 H. Green, Pack My Bag. A Self Portrait (London, 1940, 2000), p. 49.

239 P. Ariès, Western Attitudes toward Death. From the Middle Ages to the Present (Baltimore, 1974); G. Gorer, Death, Grief, and Mourning in Contemporary Britain (London, 1965). 
240 P. Jalland, Death in War and Peace. A History of Loss and Grief in England, 1914-1970 (Oxford, 2010), p. 124.

241 G. Gorer, 'The Pornography of Death', Encounter, October (1955), pp. 49-52.

242 T. Walter, 'Death in War and Peace: Loss and Grief in England 1914-1970', Mortality, 16 (2011), pp. 88-89.

243 Campbell, IWM 73/37/1.

244 An independent preparatory school for boys, founded in 1943, and attached to Westminster public school.

245 P. Campbell, The Ebb and Flow of Battle (London, 1977); Ibid., In the Cannon's Mouth (London, 1979); Ibid., Blade of Grass. The Life and Times of an Ordinary Man (Budleigh Salterton, 1986).

246 Ibid., Blade of Grass, p. 114.

247 K. McLoughlin, Authoring War. The Literary Representation of War from the Iliad to Iraq (Cambridge, 2011), p. 191.

248 J. Winter, War beyond Words. Languages of Remembrance from the Great War to the Present (Cambridge, 2017), pp. 201-202.

249 Green or 'honour' envelopes were introduced in March 1915. They were intended to provide a means for fighting men to write about private or family matters outside of the usual censorship regime.

250 C. Acton, 'Writing and Waiting: The First World War Correspondence between Vera Brittain and Roland Leighton', Gender \& History, 11:1 (1999), p. 54.

251 Michael Roper's analysis suggested that almost half (47.5 per cent) of the 80 collections he reviewed were addressed solely to mothers. Letters addressed to siblings comprised 16 per cent, with more sent to sisters than brothers. Roper, The Secret Battle, pp. 59-60.

252 Ibid., p. 62; Hartley, “'Letters Are Everything These Days”, p. 186.

253 C. Steedman, 'Enforced Narratives. Stories of Another Self', in T. Cosslett et al. (eds), Feminism and Autobiography (London, 2000), pp. 21-38.

254 L. Noakes, War and the British. Gender, Memory and National Identity (London, 1998), p. 35.

255 Letter, 9 August 1917, in Scarisbrick, My Dear Ralph, p. 122.

256 Roper, 'The Unconscious Work of History', pp. 177-178.

257 Manchester Guardian, 5 November 1914.

258 Lockwood, WYAS KC329.

259 Diary, 21-22 April 1917, E. W. Hewish, IWM 02/43/1.

260 R. McKibbon, Classes and Cultures. England, 1918-1951 (Oxford, 1998), pp. 513-515.

261 Letter, n.d., M. B. Wilkinson, IWM 09/47/1. 
262 Letters, R. H. Turner, IWM 22208.

263 Letter, 10 July 1918, C. J. Falk, IWM 06/74/1.

264 Letter, 2 June 1918, Falk, IWM 06/74/1.

265 M. J. Maynes et al. (eds), Telling Stories. The Use of Personal Narratives in the Social Sciences (California, 2008), p. 82.

266 M. Jolly, 'Love Letters versus Letters Carved in Stone: Gender, Memory and the "Forces Sweethearts" Exhibition', in M. Evans and K. Lunn (eds), War and Memory in the Twentieth Century (Oxford, 1997), p. 111; R. Holmes, Tommy. The British Soldier on the Western Front, 1914-1918 (London, 2004).

267 S. Stowe, 'Making Sense of Letters and Diaries', History Matters: The U.S. Survey Course on the Web (2002), date accessed: 31 June 2018, historymatters.gmu.edu/mse/letters/.

268 Brittain, Chronicle of Youth, pp. xvii, 296.

269 A. Vernon, 'No Genre's Land: The Problem of Genre in War Memoirs and Military Autobiographies', in A. Vernon (ed.), Arms and the Self (Kent, OH, 2005), p. 23.

270 Brittain, Testament of Youth, p. 12.

271 Wrench, IWM 85/51/1.

272 A. C. Arnold, IWM 06/54/1.

273 P. C. Rosenblatt, Bitter, Bitter Tears. Nineteenth-Century Diarists and Twentieth-Century Grief Theories (Minneapolis, 1983), p. 107.

274 See, for example, the 48 letters sent by Dorothy Pickford to her sister, Mary, detailing her service as a Queen Mary's Army Auxiliary Corps administrator. Dorothy Pickford, IWM 11301.

275 Meyer, Men of War, p. 48.

276 R. Cowen (ed.), A Nurse at the Front. The First World War Diaries of Sister Edith Appleton (London, 2012).

277 Diary, 25 May 1918, H. Allott, IWM 14/33/1.

278 R. Harvey, Liddle WWI/GS/0723.

279 Imperial War Museum, 'A Closer Look at the Bond of Sacrifice' (2018), date accessed: 5 December 2018, iwm.org.uk/history/a-closerlook-at-the-bond-of-sacrifice-collection.

280 Acton, 'Writing and Waiting', p. 62; C. Makepeace, 'Living Beyond the Barbed Wire: The Familial Ties of British Prisoners of War Held in Europe during the Second World War', Historical Research, 86:231 (2012), p. 163; Roper, The Secret Battle, pp. 49-50, 66.

281 M. Hanna, 'A Republic of Letters: The Epistolary Tradition in France During World War I', American Historical Review, 108:5 (2003), p. 1348.

282 Letter, 6 December 1916, Isaac Skellern, IWM 03/15/1. 
283 W. A. Miller, Liddle WW1/GS/1103.

284 H. P. M. Jones, War Letters of a Public School Boy. With a Memoir by His Father Harry Jones (London, 1918).

285 O. Dent, A V.A.D. In France (London, 1917), pp. 335-336.

286 Letter, 21 June 1916, Harvey, Liddle WWI/GS/0723.

287 Letter, 3 January 1918, Heaton, IWM 03/29/1.

288 Letter, n.d., Povey, IWM 08/147/1.

289 D. Englander, 'Soldiering and Identity: Reflections on the Great War', War in History, 1:3 (1994), p. 305.

290 P. Boyden, Tommy Atkin's Letters: The History of the British Army Postal Service from 1795 (London, 1990), p. 28.

291 Englander, 'Soldiering and Identity', p. 304.

292 P. Fussell, The Great War and Modern Memory (Oxford, 1975, 2000), pp. 183-184.

293 Ibid., pp. 83-87; C. Hämmerle, 'You Let a Weeping Woman Call You Home? Private Correspondence During the First World War in Germany and Austria', in R. Earle (ed.), Epistolary Selves (Aldershot, 1999), pp. 161-162.

294 Bourke, Dismembering the Male, pp. 22-23; H. B. McCartney, Citizen Soldiers. The Liverpool Territorials in the First World War (Cambridge, 2005), pp. 90-91; Roper, The Secret Battle, pp. 63-64.

295 D. Todman, The Great War. Myth and Memory (London, 2005), p. 10.

296 The Times, 1 January 1916.

297 Atkins, We Grew Up Together, p. xiii; Damousi, The Labour of Loss, p. 121.

298 Letter, 22 January 1915, J. Tavernor, IWM 09/6/1.

299 Brittain, Testament of Youth, p. 142; Ibid., Chronicle of Youth, p. 173.

300 Letter, 8 June 1915, M. Lennon, IWM 08/36/1.

301 Letters, 5 and 21 December 1916, S. Goodman, IWM 97/26/1.

302 Letter, 7 April 1918, J. Pearce, IWM 13303.

303 J. Sams, IWM 02/551/1.

304 Letter, 28 March 1915, B. Evers, Liddle WW1/GS/0532.

305 Hartley, “'Letters Are Everything These Days”, 185.

306 Atkins, We Grew Up Together, xvii.

307 Letter, 17 May 1916, A. G. Sadd, IWM 96/57/1.

308 This was not universal across all nationalities, see, Hanna, 'A Republic of Letters', p. 1343; Ibid. 'War Letters: Communication between Front and Home Front', 1914-1918 Online (2014), date accessed: 
5 December 2015, encyclopedia.1914-1918-online.net/article/war_ letters_communication_between_front_and_home_front; Roper, The Secret Battle, p. 59.

309 E. Alcock, IWM 14/33/1.

310 Letter, n.d., Povey, IWM 08/147/1.

311 Hanna, 'A Republic of Letters', p. 1361; Roper, The Secret Battle, pp. 62-63.

312 Mitchison, You May Well Ask, pp. 41-42.

313 Roper, The Secret Battle, p. 67; Watson, Fighting Different Wars, pp. $48-50$.

314 Postcard, 6 December 1914, A. Mudie, IWM 1197.

31529 June 1916, A. Hubbard, IWM 22009.

316 Letter, November 1917. Cited by, L. Housman (ed.), War Letters of Fallen Englishmen (Philadelphia, 1930, 2002).

317 Letter, 16 September 1916, Collection of letters sent by four brothers, IWM 161111.

318 Letter, 8 October 1916, Collection of letters sent by four brothers, IWM 161111.

319 Interview, C. H. R. Gee, IWM 13717.

320 A. Bliss, As I Remember (London, 1989), p. 32.

321 Letter, 27 May 1917, W. T. King, IWM 89/7/1.

322 Letter, 4 February 1917, Falk, IWM 06/74/1.

323 Occasionally, the 'inner circle' was extended to include Luard's father, and brother Percy. C. Hallett and T. Luard, 'Kate Luard (1872-1962) - Professional Nurse and Witness to War', in J. Stevens and C. Stevens (eds), Unknown Warriors, 1930, 2017), pp. 10-11.

324 Letter, 21 October 1915, cited in Ibid., pp. 12-13.

325 For further background on the regime's harshness see, D. Boulton, Objection Overruled (London, 1967), pp. 166, 220; M. Hobhouse, 'I Appeal Unto Caesar'. The Case of the Conscientious Objector (London, 1917).

326 Letter, 7 January 1918, P. Wall, IWM 86/53/1.

327 Letter, 21 October 1917, Wall, IWM 86/53/1.

328 S. Hynes, The Soldiers' Tale. Bearing Witness to Modern War (London, 1997), pp. 4-6.

329 Samuel Hynes coined the phrase 'old man looking back'. A. Vernon (ed.), Arms and the Self. War, the Military, and Autobiographical Writing (Kent, OH, 2005), p. 12; Hynes, The Soldiers' Tale, p. xiv.

330 Valerie Sanders has noted the prevalence of fraternal tropes in wartime memoirs written by sisters: Sanders, The Brother-Sister Culture, pp. $57,160$. 
331 V. Stewart, “"War Memoirs of the Dead”: Writing and Remembrance in the First World War', Literature and History, 14:2 (2005), pp. 49-50.

332 Brockmeier draws on Clifford Geertz's interpretive cultural anthropology, J. Brockmeier, Beyond the Archive. Memory, Narrative, and the Autobiographical Process (Oxford, 2015), p. 129; C. Geertz, The Interpretation of Cultures (New York, 1973), pp. 310-323.

333 L. Abrams, Oral History Theory (London, 2010), pp. 78-79; A. Kuhn, Family Secrets: Acts of Memory and Imagination (London, 1995), p. 5.

334 Meyer, Men of War, p. 11.

335 Strange, 'Fatherhood, Providing and Attachment', p. 1018.

336 Roper, 'The Unconscious Work of History', p. 170.

337 B. London, 'Writing Modern Deaths: Women, War, and the View from the Home Front', in H. Laird (ed.), The History of British Women Writing, 1880-1920: Volume 7 (London, 2016), p. 289.

338 Winter, Sites of Memory, pp. 221-222.

339 E. Marsh, Rupert Brooke. A Memoir (London, 1918); Times Literary Supplement, 11 December 1919.

340 Stewart, "“War Memoirs of the Dead"', p. 38.

341 London, 'Writing Modern Deaths', pp. 289-290.

342 J. Robinett, 'The Narrative Shape of Traumatic Experience', Literature and Medicine, 26:2 (2007), p. 291.

343 J. Clancy, 'Introduction', The World of Kate Roberts. Selected Stories 1925-1981 (Philadelphia, 1991), p. xi.

344 Ouditt, Fighting Forces, p. 217.

345 A. L. Stoler and K. Strassler, 'Memory Work in Java: A Cautionary Tale', in R. Perks and A. Thomson (eds), The Oral History Reader (London, 2016), pp. 375-377.

346 The BBC, the IWM and Sir Peter Liddle conducted oral history interviews with Great War veterans in the latter decades of the twentieth century.

347 Notable examples include, M. Arthur, Forgotten Voices of the Great War (London, 2002); P. Hart, Voices from the Front. An Oral History of the Great War (London, 2015); P. Vansittart, Voices from the Great War (London, 1981).

348 The 1970s and 1980s saw a proliferation of working-class autobiographies. See, C. Waters, 'Autobiography, Nostalgia, and the Changing Practices of Working-Class Selfhood', in G. Behlmer and F. Leventhal (eds), Singular Continuities (Stanford, 2000), pp. 180-187.

349 J. Winter, 'The Generation of Memory: Reflections on the Memory Boom in Contemporary Historical Studies', Bulletin of the German 
Historical Institute, 27: Fall (2000), pp. 5-13; Ibid., Remembering War. The Great War between Memory and History in the Twentieth Century (New Haven, 2006), pp. 17-51.

350 B. London, 'Posthumous Was a Woman: World War I Memorials and Woolf's Dead Poet's Society', Woolf Studies Annual, 16 (2010), pp. 46-47; M. Connelly, The Great War, Memory and Ritual. Commemoration in the City and East London 1916-1939 (Woodbridge, 2002).

351 Brockmeier, Beyond the Archive, p. 15; Winter, Remembering War, pp. 43-48.

352 Patch was one of the last surviving veterans of trench warfare.

353 Winter, 'The Generation of Memory', p. 9.

354 Scarisbrick, My Dear Ralph, pp. ix-x.

355 Independent, 5 August 2004. 